Proceedings of the Geologists' Association 127, 716-737 (2016). Author accepted manuscript. http://dx.doi.org/10.1016/j.pgeola.2016.10.002

\title{
Progress in marine geoconservation in Scotland's seas: assessment of key interests and their contribution to Marine Protected Area network planning
}

\author{
John E. Gordon ${ }^{a^{*}}$, Anthony J. Brooks ${ }^{\mathrm{b}}$, Peter D. Chaniotis ${ }^{\mathrm{c}}$, Ben D. James ${ }^{\mathrm{d}}$, Neil H. \\ Kenyon $^{\mathrm{e}}$, Alick B. Leslie ${ }^{\mathrm{f}}$, David Long ${ }^{\mathrm{g}}$, Alistair F. Rennie ${ }^{\mathrm{d}}$ \\ ${ }^{a}$ School of Geography \& Geosciences, University of St Andrews, St Andrews KY16 9AL, \\ Scotland, UK \\ ${ }^{\mathrm{b}}$ ABPmer, Quayside Suite, Medina Chambers, Town Quay, Southampton SO14 2AQ, \\ England, UK \\ ${ }^{\mathrm{c}}$ Joint Nature Conservation Committee, Inverdee House, Baxter Street, Aberdeen AB11 9QA, \\ Scotland, UK \\ ${ }^{\mathrm{d}}$ Scottish Natural Heritage, Great Glen House, Leachkin Road, Inverness IV3 8NW, \\ Scotland, UK \\ ${ }^{\mathrm{e}}$ Kenyon MarineGeo, 3 Broom Park, Teddington TW11 9RN, England, UK \\ ${ }^{f}$ Historic Environment Scotland, 7, South Gyle Crescent, Edinburgh EH12 9EB, Scotland, \\ UK \\ ${ }^{\mathrm{g}}$ British Geological Survey, Lyell Centre, Research Avenue South, Edinburgh EH14 4AP \\ Scotland, UK \\ *Corresponding author. \\ E-mail address: jeg4@st-andrews.ac.uk (J.E. Gordon)
}

\begin{abstract}
Geoconservation in the marine environment has been largely overlooked, despite a wealth of accumulated information on marine geology and geomorphology and clear links between many terrestrial and marine features. As part of the wider characterisation of Scotland's seas, this study developed criteria and a methodology that follow the established principles of the terrestrial, Great Britain-wide geoconservation audit, the Geological Conservation Review, to assess geodiversity key areas on the seabed. Using an expert judgement approach, eight geodiversity feature categories were identified to represent the geological and geomorphological processes that have influenced the evolution and present-day morphology of the Scottish seabed: Quaternary of Scotland; Submarine Mass Movement; Marine Geomorphology of the Scottish Deep-Ocean Seabed; Seabed Fluid and Gas Seep; Cenozoic Structures of the Atlantic Margin; Marine Geomorphology of the Scottish Shelf Seabed; Coastal Geomorphology of Scotland; and Biogenic Structures of the Scottish Seabed. Within these categories, 35 key areas were prioritised for their scientific value. Specific interests range from large-scale landforms (e.g. submarine landslides, sea-mounts and trenches) to fine-scale dynamic features (e.g. sand waves). Although these geodiversity interests provided supporting evidence for the identification and selection of a suite of Nature Conservation Marine Protected Areas (MPAs) containing important marine natural features, they are only partially represented in these MPAs and existing protected areas. Nevertheless, a pragmatic
\end{abstract}


approach is emerging to integrate as far as possible the conservation management of marine geodiversity with that of biodiversity and based on evidence of the sensitivity and vulnerability of geological and geomorphological features on the seabed.

Keywords: Marine geodiversity; geoheritage; geoconservation assessment; ecosystem approach; Marine Protected Areas; Geological Conservation Review

\section{Introduction}

Until recently, in Scotland and elsewhere, marine geoconservation has received relatively little attention compared to the conservation of geoheritage in the terrestrial environment (Burek et al., 2013). However, this is now changing as a consequence of a growing body of information on marine geology and geomorphology, improved mapping of seabed features using new remote survey techniques, greater awareness of threats, better understanding of the links to biodiversity and new legislation. Although the coastline of Scotland is a striking boundary between the terrestrial and marine environments, there is a continuity of geological and geomorphological features across this boundary, from the highest mountains to the deepocean floor. Examples of this continuity include the igneous centres and flood basalts of the extensive Palaeogene Igneous Province (Bell and Williamson, 2002; Emeleus and Bell, 2005) and the Quaternary landforms and deposits produced by successive advances of the BritishIrish Ice Sheet (Bradwell et al., 2008a). In the former case, the offshore geology complements the onshore evidence from islands such as Skye and Rum and is crucial to understanding the evolution of the wider North Atlantic Igneous Province (Ritchie and Hitchen, 1996). In the latter case, as global sea level fell periodically by as much as $120 \mathrm{~m}$ or more below its present level (Rohling et al., 2009), ice sheets extended offshore to the edge of the continental shelf to the west and north of Scotland and across the floor of the North Sea before retreating back on land as the climate ameliorated and sea level rose. Consequently, the greater part of the footprint of the last British-Irish Ice Sheet and its earlier counterparts lies offshore, as revealed in remarkable detail by the recent development of new underwater survey techniques, such as multibeam swath bathymetry (Bradwell and Stoker, 2015; Dove et al., 2015). More generally, understanding of the complex geological and geomorphological evolution of the NW European continental margin since the magmatism and rifting that led to the separation of Europe and North America in the early Eocene is fundamentally dependent on integrating onshore and offshore evidence (Hall and Bishop, 2002; Stoker et al., 2005, 2010a; Holford et al., 2009, 2010). A significant part of Scotland's geodiversity and geoheritage therefore lies offshore, as documented, for example, in British Geological Survey UK Offshore Regional Reports. To put this into context, the area covered by Scotland's seas is $\sim 608,000 \mathrm{~km}^{2}$ from MHWS out to the limit of the claimed UK Continental Shelf (Fig. 1). This is over 7.5 times the size of Scotland's land area (an estimated $80,060 \mathrm{~km}^{2}$ ) (Baxter et al., 2011).

Much of the focus on nature conservation policy and management in the UK, and elsewhere, has centred on protected areas in the terrestrial environment, including the coast (Evans, 1997; Marren, 2002). However, the EU Birds Directive (1979), the Habitats Directive (1992), the OSPAR Convention (1992) and the EU Marine Strategy Framework Directive (2008) have directed attention towards the marine environment. In turn, these international measures have been transposed into UK domestic legislation through the Conservation (Natural Habitats, \&c.) Regulations 1994, the UK Marine and Coastal Access Act 2009, the Marine (Scotland) Act 2010 and the Marine Act (Northern Ireland) 2013. 
Although primarily addressing the requirements of biodiversity, these acts include provisions for marine geoconservation (Marine Scotland, 2011a; Burek et al., 2013). Also, deriving from the Convention on Biological Diversity (CBD) (1992), the ecosystem approach has become an important conservation policy driver both in the terrestrial and marine environments and is reflected in the Millennium Ecosystem Assessment (MA) (2005), the UK National Ecosystem Assessment (UK NEA) (2011), the EU Biodiversity Strategy (European Commission, 2011), A Strategy for Marine Nature Conservation in Scotland's Seas (Marine Scotland, 2011a), the 2020 Challenge for Scottish Biodiversity (Scottish Government, 2013) and Scotland's National Marine Plan (Scottish Government, 2015). It requires a holistic approach that values both geodiversity and biodiversity and the interactions between them (Gray et al., 2013).

At the same time, there has been growing interest globally in the geomorphology of the seafloor (Chiocci and Chivas, 2014; Harris et al., 2014; Dowdeswell et al., 2016). From a conservation viewpoint, this includes benthic marine environment mapping and seabed characterisation to inform a spatial approach to marine conservation through Marine Protected Areas, based on biophysical indicators of benthic habitats and ecosystems as abiotic surrogates for biological communities and species diversity (Roff et al., 2003). Examples include the international GeoHab (Marine Geological and Biological Habitat Mapping) initiative (Todd and Greene, 2007; Heap and Harris, 2011; Harris and Baker, 2012), the MAREANO (Marine AREal Database for NOrwegian Waters) mapping programme in Norway (Dolan et al., 2009; Thorsnes et al., 2009; Buhl-Mortensen et al., 2015a, b) and MAREMAP in the UK (Diesing et al., 2014; Howe et al., 2015a). Amid growing concerns about human impacts, the legal regimes governing seafloors are moving from a focus on specific activities to more comprehensive management of larger marine areas in which intact seafloors are considered an important component of a healthy marine environment (Markus et al., 2015). This is reflected in the requirement under the EU Marine Strategy Framework Directive to include seafloor integrity as a component of 'good environmental status' (Rice et al., 2012). As part of an integrated approach, such developments offer significant opportunities to develop the geoconservation agenda in the marine environment (Henriques et al., 2011; Gordon et al., 2012; Burek et al., 2013; Prosser et al., 2013).

In Scotland, the value of an integrated approach was highlighted in A Strategy for Marine Nature Conservation in Scotland's Seas (Marine Scotland, 2011a) and in the identification of Nature Conservation Marine Protected Areas (MPAs) that incorporate geodiversity interests as part of the process, particularly where evidence suggests that these have functional links with biodiversity interests (Marine Scotland, 2011b). Scotland's National Marine Plan (Scottish Government, 2015) also recognises the value of geodiversity and the need to consider its conservation management. However, although the submarine landscape and its characteristic features form a significant component of the geodiversity and geoheritage of Scotland, there has been no systematic assessment of the importance of marine geoheritage comparable to the Geological Conservation Review (GCR) geoconservation audit completed for the terrestrial geology and geomorphology of Great Britain (Ellis et al., 1996; Ellis, 2011). Nor has there been a systematic assessment of the role of geodiversity in supporting biodiversity in Scotland's seas. In this paper, we address the first of these issues and highlight the second as a research priority. We outline the statutory context for marine conservation in Scotland and the nature and scientific importance of Scotland's marine geodiversity. We then apply a geoconservation assessment methodology to identify key areas of scientific importance for geodiversity on the seafloor; this forms part of a broader 
programme to characterise the biodiversity and geodiversity of Scotland's marine environment. Finally, we evaluate possible threats and the progress of marine geoconservation in Scottish seas, in particular the contribution of geodiversity to the identification of search locations and the subsequent selection of Nature Conservation MPAs, and the extent to which these MPAs and other Marine Protected Areas incorporate, and offer protection to, key geoheritage interests.

\section{Marine Protected Areas: legislative and policy context}

As noted above, marine conservation in Scottish waters is underpinned by a range of international, European and UK measures and obligations (Hopkins et al., 2016). These have focused on species and habitats of European importance which are listed in the relevant annexes of the EC Birds and Habitats Directives. Under the Nature Conservation (Scotland) Act 2004, Scottish Natural Heritage (one of the statutory nature conservation bodies in Scotland) also has powers to notify parts of the intertidal area and adjacent coastal land as Sites of Special Scientific Interest (SSSIs) to protect important biodiversity and geodiversity features. Marine conservation and the development of strategic planning for Scotland's seas is now a key priority as set out in the Marine (Scotland) Act 2010 which applies to the area inside 12 nautical miles. This provides the legal mechanism to help ensure "a clean, healthy, safe, productive and biologically diverse marine and coastal environment that meets the long term needs of people and nature", by putting in place a new system for improved management and protection of the marine and coastal environment (Marine Scotland, 2011a). It introduces a duty to protect and enhance the marine environment and includes measures to streamline licensing for developments in sectors such as marine renewables. Measures for marine planning and conservation allow for conservation of features of geological or geomorphological interest through designation as Nature Conservation MPAs (paragraph 68). The UK Marine and Coastal Access Act 2009 includes equivalent provisions for Scottish Ministers to designate MPAs for biodiversity and geodiversity features in offshore waters adjacent to Scotland. These provisions will enable Scottish Ministers to help fulfil international commitments under the OSPAR Convention to establish an ecologically coherent network of well-managed MPAs across the North-east Atlantic (Fig. 1). The MPA network in Scotland's seas comprises existing MPAs (primarily European Marine Sites Special Areas of Conservation (SACs) and Special Protection Areas (SPAs) - designated under the EU Habitats and Birds Directives, as well as those subject to other types of areabased management, including marine components of SSSIs and Ramsar sites) and Nature Conservation MPAs designated under the recent legislation. In terms of geoconservation, Nature Conservation MPAs are considered appropriate (Marine Scotland, 2011b, p. 15) for contributing to the protection of:

- areas of nationally and/or internationally important geological or geomorphological features;

- areas of exceptional and/or threatened geological or geomorphological features; and/or

- areas of geological or geomorphological features representative of key aspects of the marine geodiversity of UK waters.

The selection process for Nature Conservation MPAs involved five stages (Marine Scotland, 2011b):

1. the identification of search locations containing MPA search features; 
2. the prioritisation of search locations according to the qualities of the MPA search features they contain;

3. assessment of the appropriate scale of the search locations;

4. assessment of the potential effectiveness of managing the features; and

5. assessment of the contribution the areas might make to an ecologically coherent network of MPAs.

The identification of search locations containing priority marine natural features required, as a first step, the identification of key biodiversity and geodiversity interests through a robust scientific framework with supporting justification. In summary, for an area to be identified as an MPA search location containing important marine natural features (either biological, geological or geomorphological), at least one of the following Stage 1 guidelines must be met (Table 1):

- presence of key marine natural features;

- presence of features considered to be under threat and/or subject to rapid decline;

- areas considered to be critical to the functioning of wider marine ecosystems.

For geodiversity features, the guideline specifications were developed to include analogous 'criteria' to those of the GCR, but were incorporated in a single unified system with the biodiversity guidelines to ensure a holistic approach (Marine Scotland, 2011b). However, in practice, priority for the selection of MPAs is given to biodiversity locations, with geodiversity providing a supporting role. Consequently, the geodiversity assessment focused mainly on geological and geomorphological features on the seabed. Such features are also likely to be more vulnerable to human impacts than sub-seafloor interests. The characterisation and assessment of geodiversity key areas helped to inform the Nature Conservation MPA selection process by providing evidence on the scientific importance of geodiversity features and their geographic-distributions.

\section{Methodology}

Previous conservation assessments of geological and geomorphological features in the UK marine environment through pilot studies at both regional (Furze and Roberts, 2004) and national (Brooks et al., 2009) levels have involved the application of scoring schemes to evaluate the importance and vulnerability of individual features or groups of features on the seabed. Feature importance was determined using criteria of exceptionality, proportional importance and rarity. Such an approach, however, involves the assessment of features in isolation and in the absence of their geoscientific context as part of networks of related sites. In contrast, nationally and internationally important sites in the terrestrial environment have been identified through the scientific framework of the GCR (Ellis, 2011). This involves the establishment of the principal geoscience features, or 'blocks', of interest (e.g. Quaternary of Scotland, Mass Movement, Coastal Geomorphology), followed by a systematic evaluation and prioritisation of key sites within these blocks (Ellis, 2011). The sites, selected by a process of expert review, form networks of related interests and are supported by substantive scientific evidence and context. They make a special contribution to the understanding and appreciation of the geoheritage of Great Britain through their international importance or 
inclusion of exceptional features, or they are representative of fundamental features, events and processes in the geological history of Britain.

In the present study, to ensure comparability, we followed the established and successful methodology and principles of the GCR, including expert review of the scientific evidence (Brooks et al., 2013). However, the requirement to be wholly consistent with the Scottish MPA Selection Guidelines resulted in some differences (Table 1). For the purposes of identifying MPA search locations, the concept of importance includes features that are under threat as well as areas of the seabed that are considered to be critical to the overall functioning of the marine ecosystem (Table 1). Another difference is the manner in which the rarity of a feature is taken into consideration. Under the MPA Selection Guidelines, feature rarity by itself is of no significance because rarity in the marine environment is often an artefact of under-recording. This contrasts with the terrestrial environment where, primarily as a result of the ease with which the landscape can be accessed and mapped, considerably more is known about the spatial distribution of geological and geomorphological features.

A significant consideration in geoconservation assessment, both in terrestrial and marine environments, is that scientific importance is often determined not simply by the presence or absence of a particular interest, but rather by the interpretation(s) placed upon it. For example, a well-dated moraine or group of moraines indicating a particular event, such as the limits of the last British-Irish Ice Sheet on the continental shelf edge west of Shetland and the Outer Hebrides or a significant retreat phase, will have greater significance than other undated or unattributed moraines. Often, too, particularly in the case of geomorphological features, the assemblage of interests and their inter-relationships are crucial. For example, an assemblage of landforms (lineations, moraines and trough-mouth fan) indicating the presence of a fast-flowing palaeo-ice stream will generally be more important than individual landforms in revealing ice-sheet dynamics. Consequently, in such cases, a landsystem approach involving large areas may be required for geoconservation, rather than small individual sites.

The starting point of this desk-based study was a categorisation of thematic subject blocks (feature categories) incorporating the range of key marine geodiversity interests on the Scottish seabed that satisfy the Scottish MPA Selection Guidelines (Brooks et al., 2013). The large-scale physiography of the Scottish seabed comprises: the continental shelf; continental slope; deep-ocean basin; and deep-ocean bathymetric rises. At a more local scale, wide variations in seabed topography and sediments are influenced by the structure and composition of the underlying bedrock, the configurations and properties of features originating at former terrestrial and submarine ice-sheet margins and beds, submarine mass movements, carbonate biological sedimentary input, and past and present near-bed currents (Holmes et al., 2004; Brooks et al., 2013). This geodiversity can be broadly categorised into eight thematic blocks (Table 2). Together, these represent the geological and geomorphological processes that have shaped the evolution and present geomorphology of the Scottish seabed and continue to modify it. Like the blocks of the terrestrial GCR, they include interests and areas of national and international importance, form an integral part of Scotland's geoheritage and in many cases support important biodiversity interests. Three of the blocks, Quaternary of Scotland, Coastal Geomorphology of Scotland and Submarine Mass Movement, correspond with respective terrestrial GCR blocks (Gordon and Sutherland, 1993; May and Hansom, 2003; Cooper, 2007), reflecting common processes that have shaped both the terrestrial landscape and the seabed. However, other geodiversity interests on the 
Scottish seabed have formed through processes that are unique to the marine environment. Together, the eight blocks represent the MPA search features for geodiversity.

A provisional list of key areas was initially compiled using expert judgement and existing published information from a GIS database of previously identified geological and geomorphological seabed features (Brooks et al., 2009), as well as unpublished information; the term 'areas' is used rather than 'sites' as the interests often have significant geographical extent and cover assemblages of features. This list was then tested and refined at a workshop attended by invited Earth scientists with expertise and knowledge of the marine geology and geomorphology of the Scottish seabed, including Quaternary glacial geomorphology; coastal geomorphology and shallow marine seabed processes; slope instability and associated submarine mass movement processes and deep-offshore seabed processes. Following the workshop, the provisional list of key areas was revised in the light of the recommendations of the expert group, re-circulated for further comment, and then finalised. There was a consensus on both the thematic subject blocks and the key areas. Together they represent the principal elements of the marine geoheritage of the Scottish seabed based on current knowledge.

Some of the existing beach, dune and machair Coastal Geomorphology GCR sites (May and Hansom, 2003) are part of wider geomorphological systems, and their dynamics and future evolution depend on sediment supply and pathways outside the existing terrestrial site boundaries which are demarcated only down to Mean Low Water of Spring tides (MLWS). However, possible nearshore extensions to these sites were not considered in the assessment because of a lack of information on the extent of the physical processes that would enable the geomorphological system boundaries to be defined. This is an area that requires further research.

\section{The nature and scientific importance of Scotland's marine geodiversity}

Many of the Scottish rocks and landforms in the terrestrial environment have, over the past 200 years or so, provided fundamental insights into Earth history and processes of global significance. Increasingly, Scottish marine geodiversity features are providing similarly critical understanding (Table 2) (Brooks et al., 2013; Gordon et al., 2013). In summary, although individual features such as glacial bedforms, submarine slides and sites with long sedimentary records, inter alia, occur elsewhere on the North-west European margins (Nielsen et al., 2005; Dowdeswell et al., 2016), the marine geodiversity of Scottish waters is outstanding for the assemblage of features present, notably the particular combination of Palaeogene volcanism and rifting, Cenozoic structural blocks, post-rifting evolution (uplift/exhumation and subsidence/burial), glacial features related to expansion and contraction of the British-Irish Ice Sheet, high benthic carbonate production and marine geomorphological processes. Sea level has also fluctuated, allowing a range of marine, coastal and subaerial processes to operate over the shelf at different times. For a country of Scotland's size, the resulting geodiversity is exceptional and has a significant bearing on understanding the evolution of 'passive' continental margins, the dynamics of marine-based ice sheets and their coupling with climate and ocean circulation patterns, submarine mass movements, sea-level changes and contemporary marine geomorphological processes.

In addition, as in the terrestrial environment (Gordon and Barron, 2013), Scotland's marine geodiversity is important not only for its inherent geoheritage values, but also for the 
wider ecosystem services and benefits it provides (Scottish Government, 2015). Geological and geomorphological processes have shaped the large-scale physiography of the Scottish seabed, so that the special character and natural diversity of Scotland's seas have been influenced to a large degree by the interaction of the geological evolution and geographical location in relation to major ocean currents. The cumulative imprint of the tectonic evolution of the continental margin during the Cenozoic, processes of pre-glacial erosion and deposition, multiple glaciations and sea-level change contributes significantly to the diversity of the physiography, and hence marine habitats, at different scales, viz:

- the large-scale physiography, comprising continental shelf, slope, deep ocean and deep-ocean rises, which influences hydrographic environments and processes;

- the regional-scale physiography, comprising shelf features (islands, sheltered fjord coasts, bays, banks, mounds) and deep-ocean features (basins, troughs, sediment plains, seamounts, banks), which influences more local habitat opportunities and diversity.

Scotland's seas represent a huge environmental, economic and recreational asset, essentially underpinned by geodiversity. In particular, there are clear relationships between marine geodiversity and ecosystem support for healthy, diverse seas, offshore development (oil, gas and renewables) and fisheries, as well as a range of other regulating, supporting, provisioning and cultural services including attenuation of wave energy close to shore and storage of blue carbon in marine sediments (Table 3) (Baxter et al., 2011; Scottish Government, 2015).

The remainder of this section provides a brief characterisation of each of the eight marine geodiversity blocks and the scientific context for the assessment of the key areas.

\subsection{The Quaternary of Scotland}

During the Quaternary, thick ice sheets accumulated over Scotland and adjacent continental shelves on at least five separate occasions (Holmes, 1997; Merritt et al., 2003; Thierens et al., 2012). The landforms and deposits produced by these ice sheets have had a major influence on the morphology and physical characteristics of the Scottish seabed (Brooks et al., 2013; Gordon et al., 2013). During part of the last (Late Devensian) glaciation between c. 30,000 and 25,000 years ago, and during earlier glaciations (Holmes, 1997; Lee et al., 2012), the Scottish ice sheet formed part of a larger British-Irish Ice Sheet extending to the shelf edge and locally coalescing with Scandinavian ice in the North Sea basin (Stoker et al., 1993; Bradwell et al., 2008a; Sejrup et al., 2009). Fast-flowing ice streams within the ice sheet incised deep channels across the shelf to the west and north-west of Scotland and formed streamlined bedforms (Stoker and Bradwell, 2005; Bradwell et al., 2007; Bradwell et al., 2008b; Dunlop et al., 2010; Howe et al., 2012; Dove et al., 2015). The presence of palaeoice streams and associated bedforms and channels has also been documented in the Moray Firth (Finlayson et al., 2008), eastern Scotland (Golledge and Stoker, 2006) and the Witch Basin (Graham et al., 2007).

Almost all the shelf troughs terminate with extensive prograding wedges that form trough-mouth fans spanning the shelf-slope-basin floor region (Stoker, 1995; Dahlgren et al., 2005): the Barra and Sula Sgeir fans to the north-west of Scotland and the Rona, Foula and North Sea Fans to the north and north-east. All of these large fans, and adjacent shelf slopes, 
contain records of sedimentation stretching back many hundreds of thousands of years and thus represent extremely valuable archives of Quaternary glacial history (Stoker et al., 1994; Scourse et al., 2009; Hibbert et al., 2010).

On the shelf, sonar, seismic and swath bathymetry data have revealed the extensive occurrence of moraine ridges recording the limits and pattern of decay of the British-Irish Ice Sheet, both north and west of Scotland and in the North Sea basin (Stoker and Holmes, 1991; Bradwell et al., 2008a; Graham et al., 2009; Clark et al., 2012; Bradwell and Stoker, 2015; Dove et al., 2015). At the outer shelf edge, moraines commonly occur as large arcuate ridges, 2-10 km wide and several 10s of kilometres long (Stoker et al., 1993; Bradwell et al., 2008a). These forms differ greatly from the much smaller 'De Geer' moraines deposited in shallow water settings within the fjordic environment of the Summer Isles (Stoker et al., 2009). In the North Sea, Wee Bankie and Bosies Bank are large offshore moraine complexes that have played a central role in the debate regarding the offshore extent of ice in the North Sea basin during the last glacial period. Until recently, they were regarded as end moraines, marking the maximum easterly extent of the British-Irish Ice Sheet (Sutherland, 1984a; Bowen et al., 2002). However, the discovery of glacial features in the central North Sea to the east of the moraines (Graham et al., 2007, 2010; Sejrup et al., 2009) indicates that Bosies Bank and Wee Bankie formed after the Last Glacial Maximum, either as part of the dynamic retreat, or during a readvance, of the British-Irish Ice Sheet.

To the east of Scotland, groups of sub-glacial tunnel valleys form spectacular trenches several hundreds of metres deep (Bradwell et al., 2008a; Stewart et al., 2013). They include the Southern Trench, the Devil's Hole and Fladen Deeps, which are thought to have been cut by highly pressurised water flowing beneath the ice. These valleys form part of a much wider network of similar trenches mapped across the North Sea basin (van der Vegt et al., 2012) and in the North Channel of the Irish Sea (Callaway et al., 2011). They are scientifically important for interpreting past changes in the extent and geometry of British-Irish Ice Sheets (Bradwell et al., 2008a) and their patterns of retreat (Stewart et al., 2013); different generations of tunnel valleys also indicate multiple glacial cycles (Stewart and Lonergan, 2011) and changes in the dynamics of the British-Irish and Scandinavian Ice Sheets between different glaciations (Stewart et al., 2013). Tunnel valleys play a central role in meltwater drainage beneath ice sheets (Lonergan et al., 2006), and studies of these landforms may help to provide improved models of the response of modern ice sheets to likely future climate change.

A number of other glacial features are characteristic of the Scottish seabed. The calving fronts of the fast-flowing ice streams that extended across the shelf would have been a productive source of large icebergs. With keels several hundreds of metres below the surface, they ground shallow furrows (iceberg ploughmark fields) into the seafloor sediments, especially on the outer shelf and upper slope down to about $500 \mathrm{~m}$ water depth (Belderson et al., 1973). Proglacial features, including sub-aerial meltwater channels and glacial outwash deposits, formed beyond the melting ice-sheet margins. West of the Outer Hebrides, landscapes of areal scouring formed by extensive subglacial abrasion extend over the large area of Precambrian outcrop (Kenyon and Pelton, 1979).

The glacial landform and sedimentary records are important for understanding the dynamics of marine-based ice sheets under changing climates and the linkages between ocean circulation and climate change. Because of its extreme maritime location, the British-Irish Ice Sheet is considered to have been particularly sensitive to climate changes (Hibbert et al., 
2010; Thierens et al., 2012). Although important, the terrestrial evidence represents only a small, and often discontinuous, part of the ice-sheet footprint. Since the ice sheet was largely marine-based, much of the evidence is offshore in the form of geomorphology (Sejrup et al., 2005; Bradwell et al., 2008a) and dateable sedimentary records (Peters et al., 2008; Scourse et al., 2009; Graham et al., 2010; Hibbert et al., 2010). The importance of this evidence is underlined by Sejrup et al. (2009) who considered that the North Sea region "most likely possesses the best dated marine-based Late Pleistocene ice sheet in the world".

As noted above, the Scottish seabed contains an abundance of bedforms associated with marine-based ice sheets characterised by the presence of fast-moving ice streams. There are significant gaps in understanding the dynamics of such ice streams, although they are critical to the behaviour and functioning of contemporary ice sheets, such as those in Greenland and Antarctica (Stoker and Bradwell, 2005). Research on palaeo-ice streams on the Scottish shelf has the potential to play a valuable part in addressing this knowledge deficit. The last decade has seen significant progress in this area as a result of the availability of offshore data, combined with advances in mapping and robust dating of onshore and offshore evidence and whole ice-sheet modelling (D.J.A. Evans et al., 2005; Boulton and Hagdorn, 2006; Bradwell et al., 2008a; Hubbard et al., 2009; Chiverrell and Thomas, 2010; Clark et al., 2012).

Offshore evidence has also been vital for interpreting the deglacial history and behaviour of different sectors of the British-Irish Ice Sheet (Scourse et al., 2009) and hence understanding ice-sheet dynamics and links to climate forcing and other factors such as sea level and calving (Bradwell et al., 2008a). In turn, this is enabling insights into wider Earth system processes and the coupling of ice-sheet dynamics, ocean processes, climate, the rheology of the upper mantle, glacio-isostatic adjustment and relative sea-level change (Milne et al., 2006; Bradley et al., 2011). Such understanding is not only of academic interest but is of critical importance in informing assessments of the future responses of modern marine-based ice sheets to likely 21 st century climate warming, sea-level rise and possible changes in ocean circulation (Clark et al., 2012; Ó Cofaigh, 2012). For example, the British-Irish Ice Sheet may be an analogue for the marine-based West Antarctic Ice Sheet, the future stability of which is a key concern in a warmer world (Vaughan and Arthern, 2007; Lenton et al., 2008), and help to provide empirical evidence to test numerical models of dynamic, fastflowing ice sheets (Boulton and Hagdorn, 2006; Hubbard et al., 2009).

The palaeoenvironmental archives contained in offshore sedimentary deposits have a length and continuity unavailable in terrestrial records. The North-East Atlantic occupies a critical location within the global ocean circulation system and was close to the position of the oceanic polar front during the last glaciation (Knutz et al., 2007). Studies of past regionalscale changes in ocean circulation from the sedimentary records in this region, notably from cores in the trough-mouth Barra Fan, Rosemary Bank and Rockall Trough, have played an important part in elucidating the links with the wider global climate system and have the potential to improve greatly our understanding of future changes. For example, they have revealed repeated marine-terminating and shelf-edge glaciations (Stoker et al., 1994; Thierens et al., 2012), regional-scale changes in palaeoceanography and climate variations at the subMilankovitch (millennial) scale (Kroon et al., 1997, 2000; Howe et al., 1998; Knutz et al., 2001, 2007; Austin and Kroon 2001; Wilson and Austin, 2002; Dickson et al., 2008;

McIntyre and Howe, 2009; Hall et al., 2011; Austin et al., 2012; Small et al., 2013), complex spatial and temporal variations in the advance and retreat of the last British-Irish Ice Sheet at millennial timescales linked to latitudinal variations in the North Atlantic Polar Front (Knutz et al., 2001, 2002, 2007; Wilson and Austin, 2002; Wilson et al., 2002; Peters et al., 2008; 
Scourse et al., 2009; Hibbert et al., 2010) and changing sedimentation patterns and processes (Kroon et al., 2000; Knutz et al., 2002).

At a more local scale, the geomorphological and sedimentary archives of the west coast fjords of Scotland augment the terrestrial evidence for the later stages of deglaciation of the last British-Irish Ice Sheet and the subsequent re-expansion of glaciers in the north and west Highlands during the Loch Lomond (Younger Dryas) Stade (Stoker et al., 2006, 2009; McIntyre and Howe, 2010; McIntyre et al., 2011; Howe et al., 2015b; Audsley et al., 2016; Small et al., 2016). The fjord sediments also record palaeoenvironmental changes during the Holocene (Howe et al., 2002; Nørgaard-Pedersen et al., 2006; Baltzer et al., 2010; Cage and Austin, 2010; Cundill and Austin, 2010; Mokeddem et al., 2010) and form sinks for organic carbon from terrestrial sources (Burrows et al., 2014).

\subsection{Submarine Mass Movement}

Submarine Mass Movement interests principally include those associated with submarine slides and turbidity currents. Large submarine slides covering many tens of $\mathrm{km}^{2}$ are a characteristic feature of the continental slope surrounding Scotland's northern and western margins (Holmes et al., 1998; D. Evans et al., 2005). They vary in terms of both age and expression: most of the older (pre-Holocene) slide deposits have been partially or completely buried within the sedimentary column, whilst other (predominantly Holocene age) slides have retained clear seabed expression. Larger slides (e.g. the Miller Slide) have lateral extents of over $50 \mathrm{~km}$, whilst smaller slides (e.g. the Afen Slide) are only a few kilometres wide (Long et al., 2003). Where there has been a movement on a basal failure surface with little internal deformation except along a series of internal fault planes, the resultant morphology at the seafloor is usually a relatively steep slide scar or several slide scars at the head of the slide. Slide deposits can consist of accumulations of coherent blocks, some of which can be very large, mixed with debris flow deposits and with turbidites. Well-studied examples include the Peach and Geikie Slides (to the west of Scotland and the Hebridean continental slope) and the (palaeo) Afen and Miller Slides (to the north of Scotland on the Scottish side of the FaroeShetland Channel continental slope), which mainly occurred during periods of rapid Quaternary sea-level rise (Leynaud et al., 2009; Smith et al., 2013). Numerous smaller slides, which occurred over the past 11,000 years or so, have been identified in the sea lochs of western Scotland (Stoker et al., 2010b).

Knowing the locations and dynamics of these slides is not only of scientific value, but also has practical relevance: for example, the Storegga Slide off western Norway caused a large tsunami that swept the seaboard of eastern Scotland c.8,100 cal. yr B.P. (Dawson et al., 2011), reaching onshore heights in Shetland at least $20 \mathrm{~m}$ above the sea level of that time (Smith et al., 2004; Bondevik et al., 2005). Understanding the dynamics of these ancient slides is important as it enables the identification of those slope areas that could experience future slide events, potentially putting marine and coastal infrastructure at risk. The Scottish seabed and coastal sequences represent a key area for research into this type of geohazard.

Turbidity currents are the main cause of erosion at the axis of continental slope turbidite canyons, examples of which are found on the Hebridean continental slope margin to the south-west of Scotland's seas. Turbidite accumulations occur mainly beyond the foot of the continental slope and especially at the mouths of slope canyons. Together with contourites, they comprise mostly the land-derived sediment that makes up the continental rises. The most extensive turbidite accumulations in Scottish waters are on the floor of the Rockall Trough 
west of the Malin Sea and west of Hatton Bank where they are sourced from southern Iceland (Elliott and Parson, 2008). The turbidite systems were, for the most part, active at times of low sea level when large quantities of sediment were transported near to the shelf edge by rivers.

\subsection{Marine Geomorphology of the Scottish Deep-Ocean Seabed}

Oceanic contour-following currents dominate the sedimentation at certain depths. The North Atlantic Current flows north along the upper slope west and north of Scotland at depths shallower than about $500 \mathrm{~m}$ and occasionally spills onto the continental shelf. The Norwegian Sea water flows south through the Faroe-Shetland and Faroe Bank Channels. Some spills across the Wyville-Thomson Ridge and then flows clockwise around Bill Bailey Bank. Both of these currents are strong enough to form sand waves.

Scour moats and erosional scour fields occur where water flows are relatively higher due to restriction by geologically determined topography. The scour moats around igneous blocks north of Hatton Bank to the far west of Scotland are 50 - 200 m deep (MacLachlan et al., 2008), whilst well-developed moats occur at the base of a number of Scottish deep-ocean rises including Anton Dohrn Seamount and Rockall, George Bligh and Rosemary Banks. Deep-sea furrows near Lousy Bank are up to $150 \mathrm{~m}$ deep.

Contourites comprise extensive accumulations of muds and silts deposited and moulded by deep-sea currents. The surfaces of these sediment drifts are in many places moulded into large sediment waves (Hohbein and Cartwright, 2006). Along the West Shetland Margin, these deposits form a complex of bedforms that are unique in UK waters and have provided one of the first detailed studies of this scientifically important sedimentary facies (Masson, 2001). The surface sands are assumed to be of Holocene age, whilst the underlying muddy drift was deposited during the Pliocene to Early-Mid Pleistocene. The sandy contourites are a rare phenomenon known from few other places than the Faroe-Shetland Channel and its extension to the west (Akhmetzhanov et al., 2007). The muddy drifts, an important part of the architecture of much of the world's continental slopes and rises, are particularly well mapped here by oil industry seismic surveys which have been used to reveal seabed morphology, including moraines and iceberg ploughmarks as well as contourites (Long et al., 2004). Analyses of some of these surveys are starting to reveal the history of currents flowing through this gateway between the Arctic and Atlantic basins, a key location for understanding past climate changes and linkages with ocean circulation (Rasmussen et al., 2002). Deepocean sediments are also significant repositories of blue carbon (Burrows et al., 2014).

\subsection{Seabed Fluid and Gas Seep}

Fluid flow at the seabed can be through thick sediments from deep-seated sources. Where the flows of water and gases reach the seabed, pockmarks (Judd and Hovland, 2007) are a characteristic feature of much of the east and north of Scotland and some, such as the Scanner Pockmark in the northern North Sea, are considered to be still active. For the most part, these features form shallow seabed depressions, typically several tens of metres in diameter and a few metres deep. However, 'giant' examples collectively form the ScannerScotia and Challenger pockmark complexes in the North Sea (Gafeira and Long, 2015).

Well-sorted sands that are overlain by less porous sediments are subject to sudden expulsion of the sand-water mixture as 'sand volcanoes'. This can result from shaking by 
earthquakes or the sudden loading by rapid deposition of sediment. The Darwin Mounds, north-west of Scotland, represent very unusual examples of this type of fluid-seep bedform (Joint Nature Conservation Committee, 2008), and these small ( $\leq 5 \mathrm{~m}$ high) mound-tail features have not yet been described from elsewhere (Masson et al., 2003).

\subsection{Cenozoic Structures of the Atlantic Margin}

Cenozoic structures include a range of features formed during the last $65 \mathrm{Ma}$ since the opening of the North Atlantic Ocean. They primarily include large structural blocks of Palaeogene igneous rocks left upstanding due to subsequent differential erosion of weaker surrounding sediments. Such large, deep-ocean bathymetric rises are characteristic of the deep waters to the far west of Scotland. Erosion of the uplifted flanks of the continent was accompanied by the deposition of large amounts of sediment into the gradually cooling and deepening oceanic basin. During the early rifting, large amounts of lava poured out along deep-seated fissures. A number of shallow igneous blocks located oceanwards of western Scotland range in size from isolated volcanic seamounts, such as the Rosemary Bank Seamount and the Anton Dohrn Seamount, up to the Wyville-Thomson Ridge and contribute significantly to forming the Rockall and Hatton banks. They have a high proportion of igneous rocks with extensive areas of sub-aerial basalts (Edwards, 2002). Small volcanic parasitic cones occur on some of these seamounts and banks (Jacobs, 2006; Stewart et al., 2009).

Dating evidence from Anton Dohrn has played a scientifically important role in advancing understanding of the volcanic history of the North Atlantic Volcanic Province (O'Connor et al., 2000). It demonstrates that the continental rifting that formed the North Atlantic volcanic province began in the Late Cretaceous (c.70 Ma), earlier than previously thought. Along with Rosemary Bank and the Hebrides Terrace Seamount, Anton Dohrn is one of the few accessible remnants of such early mantle plume activity. In addition, the region has provided a range of sedimentary and geophysical evidence that reveals the dynamic evolution of a supposed 'passive' continental margin in response to changes in upper mantle convective flow (Praeg et al., 2005; Stoker et al., 2005, 2010a; Holford et al., $2009,2010)$. In turn, the associated tectonic movements have driven responses in erosion, sedimentation and deep-ocean circulation and provided the topographic conditions to support glaciation. Such tectonic processes may be characteristic of the development of 'passive' continental margins elsewhere and help to inform interpretation of their evolution (Stoker et al., 2005).

Also included within this block are mud diapirs produced by the upward movement of relatively fluid mud that is deeply buried by less fluid sediments. The mud contains rock clasts torn from the sides of the pipe, up which it moves. Although mud diapirs are relatively common globally, the only known examples in UK waters (with a seafloor expression) are the Pilot Whale Diapirs at the north end of the Faroe-Shetland Channel (Holmes et al., 2003). The formation of these deep-water (c. 1,500 m) sediment mounds, measuring 2-3 km across and rising to more than $70 \mathrm{~m}$ above the surrounding sea floor, is related to overpressure of mobile sediments by the thick glacigenic sediment accumulation of the North Sea Fan and/or lateral tectonic compression (Ritchie et al., 2011) and can help to elucidate sub-surface fluid migration pathways within the Faroe-Shetland Channel (Ritchie et al., 2008).

These features represent the southernmost grouping of a series of replicate features that extend down the Norwegian margin, across the Vøring Plateau and Møre Basin (Hjelstuen et 
al., 1997). These mounds are formed from sediment that has been transferred to the seabed from rocks and sediments more than $24 \mathrm{Ma}$ old. Mud volcanism, subsurface injection of soft sediment and diapirism are all likely to have been involved in the development of the Pilot Whale Diapirs, although their initial development is likely to have been triggered by growth of the Pilot Whale Anticline from early Pliocene times onwards (Ritchie et al., 2008).

\subsection{Marine Geomorphology of the Scottish Shelf Seabed}

Modern marine currents are partly reworking the complex seafloor morphology constructed by all of the processes outlined previously. The currents have been eroding some of the relict features and burying others as they form a new basal bed on much of the continental shelf and on parts of the deeper seabed where the currents are strong. Some marine process features are themselves relict from times of lower sea level, such as some deep offshore tidal banks, but the majority of marine process features are formed by presentday currents (Belderson et al., 1982). The most significant types of current sweeping the shelf seafloor are tidal currents, storm-surge currents and currents induced by storm waves.

The seafloor can be divided into zones where there are characteristic bedforms controlled by peak current speed. The classic zonal sequence down the velocity gradient (Belderson et al., 1982) is from scoured rock floors where the peak current is greater than about $1.5 \mathrm{~ms}^{-1}$, to gravel wave fields and gravel furrow fields, to sand ribbon fields and, where sand is plentiful and tidal currents dominant, groups of open-shelf tidal sand banks, to large sand-wave fields, to fields of small sand waves, to fields of rippled sand to thin patches of sand where the current speed is less than about $0.4 \mathrm{~ms}^{-1}$. Many of the above features occur within the Fair Isle Channel and to the north of Scotland. However, because the influence of currents and waves on the Scottish seabed can vary considerably over short distances, many areas of Scotland's seas display a variety of different current and wave-induced bedforms. There are a few bedforms that are considered characteristic of certain current types. Tidal sand banks, such as the spectacular Sandy Riddle Bank located to the east of Scotland in territorial waters south-east of Pentland Skerries (Holmes et al., 2004), and symmetrical sand waves are only found in areas of tidal dominance. By contrast, sharp-edged sand patches are only found in areas of storm wave dominance, as are small symmetrical gravel waves.

Storm-surge currents dominate much of the middle shelf west and north of Scotland and cause eastward transport of sand through the Fair Isle Strait. Storm waves dominate areas where the directional currents (tidal, surge and oceanic) are too weak to move sand on their own. The two bedforms characteristic of storm waves are small symmetrical gravel waves and sharp-edged sand patches. Both of these bedforms occur at depths as great as $120 \mathrm{~m}$. They are found, for instance, west of Scotland, north-west of Scotland in the coastal waters around Sula Sgeir, south-west of Scotland, off the coast of Islay and in the Moray Firth (Kenyon and Cooper, 2005). In shallower water depths, less than about $20 \mathrm{~m}$, which include the tops of sand banks, tidal flats and the ramp offshore of exposed coasts, storm waves have a higher effectiveness as agents of sediment transport, especially when combined with directional currents (McCave, 1971).

The shelf areas off the Inner and Outer Hebrides and the Northern Isles are internationally important examples of non-tropical, shelf carbonate systems (Scoffin, 1988; Light and Wilson, 1998). In these areas, sands and gravels have very high carbonate content (up to 99\%) and represent important repositories of biogenic carbon (Burrows et al., 2014). It is likely that storms continue to drive part of this clastic carbonate ashore, supplying the 
carbonate sands of the important coastal dune and machair systems (Brooks et al., 2013), although the supply may be declining (Hansom and Angus, 2001). The onshore geomorphology of the machair supports highly biodiverse grassland vegetation that is recognised to be of outstanding natural heritage importance (Angus, 1994). The areas offshore of the machair are the past and present sources of the carbonate and, as such, are considered to be critical to the functioning of the wider marine and coastal ecosystem (Hansom, 2003a). The processes of breakdown and transport of clastic carbonate are complex and little known, but a requirement for machair formation seems to be a wide extent of rocky seafloor, together with an inner shelf ramp of shell sands and gravels where the tidal currents are relatively weak but the wave-induced currents are especially strong to allow onshore transport (Brooks et al., 2013).

\subsection{The Coastal Geomorphology of Scotland}

The Coastal Geomorphology of Scotland is an existing GCR category that incorporates a variety of coastal settings ranging from hard rock, high-energy coastlines to low-energy salt marsh and machair systems (May and Hansom, 2003). The machair systems are well developed within the Northern Isles and the Inner and Outer Hebrides. As noted above, the carbonate sands that support these systems are derived from adjacent offshore settings, driven shoreward through the combined action of tides and waves.

Other soft coastal GCR sites also have past and present dynamic links with nearshore sediment sources and transport processes. However, in the absence of detailed process studies it has so far proved too difficult to extend their boundaries offshore in a robust and meaningful way.

As a result of rising relative sea levels during lateglacial and postglacial times, many landforms of coastal origin, such as cliffs, caves and erosional platforms, are now found submerged offshore. Particularly outstanding examples occur off St Kilda and Sula Sgeir to the west of Scotland in territorial waters and are thought to have formed during episodes of lower sea level that occurred during Quaternary glaciations (Sutherland, 1984b, 1987; Hansom, 2003b). Submerged and intertidal peat and the tree stumps of former forests also indicate rising postglacial relative sea level, for example on Sanday and South Ronaldsay in Orkney (Rennie, 2006) and in the Hebrides and Shetland (Hoppe, 1965; Von Weymarn, 1974; Dawson et al., 2001). These features provide valuable records of Quaternary sea-level change and coastal evolution.

\subsection{Biogenic Structures of the Scottish Seabed}

Biogenic structures on the seabed are those created by marine animals and plants potentially comprising the organism itself, such as beds of maerl or horse mussels, or arising from an organism's activities or effects. Biogenic sediment mounds are elevated features composed of the skeletal remnants of scleractinian cold-water corals (mainly Lophelia pertusa and Madrepora oculata) and a veneer of sands, muds and silts. The largest are the giant carbonate mounds, for example on the margins of the Rockall Trough and Plateau (Mienis et al., 2007; Roberts et al., 2008), that can be over $300 \mathrm{~m}$ high. Their location depends on the relatively strong currents that sweep the upper part of the slope in this region, providing a food supply for the cold water coral L. pertusa. Although Lophelia is the main reef-forming coral in the North-east Atlantic, it rarely forms reef complexes in territorial waters. Mingulay Reef, at the entrance to the Sea of the Hebrides, is unique in that it is the 
only known extant area with extensive cold-water coral reefs within UK territorial waters. Lophelia reefs have been present here for many thousands of years, possibly since the early postglacial period around 11,000 years ago (Davies et al., 2009).

The horse mussel Modiolus modiolus can occur in dense beds (Holt et al., 1998) in water depths of between $5-250 \mathrm{~m}$. The structurally complex, raised biogenic habitat supports high levels of associated biodiversity, with the habitat often moulded by strong currents into low, wavy bedforms. Extensive beds of maerl, a free-living red seaweed with a hard chalky skeleton, are also widely distributed along the west coast, the Outer Hebrides and the Northern Isles. This biogenic habitat is restricted to shallow, tide-swept, sandy sea beds where sunlight can penetrate, up to around $20 \mathrm{~m}$ depth. Reefs of the polychaete worm, Sabellaria spp., are also mainly found in shallow waters, and although rare in Scottish waters, are known to occur in the north Irish Sea Basin close to the Galloway coast in the Solway Firth. Biogenic reefs and maerl beds are also important as small but long-term carbon repositories (Burrows et al., 2014).

\section{Geodiversity key areas in Scottish waters}

The methodology outlined in Section 3 was used to identify key areas for marine geodiversity on the seabed that satisfy the Scottish MPA Selection Guidelines. In total, 35 key areas were identified as being of national or international importance, grouped according to their main thematic block (Table 4 and Fig. 2). Brooks et al. (2013) provide further details of each area, including descriptions, supporting scientific statements and literature reviews. Many of the key areas contain additional supporting interests spanning multiple blocks, although the focus of information presented is on the principal interest. The largest number of sites (11) falls within the Quaternary of Scotland block. This reflects the diversity of features representing Scotland's glacial legacy and complements the coverage of the Quaternary of Scotland GCR block (Gordon and Sutherland, 1993). Similarly, the Coastal Geomorphology and Submarine Mass Movement sites complement their corresponding terrestrial networks (May and Hansom, 2003; Cooper, 2007). In some cases, the prime interest lies in individual landforms (e.g. the Scanner and Scotia Pockmarks), but in others it is not simply the presence of particular landforms but rather the assemblage of landforms, their context and the interpretations placed upon them (e.g. the palaeo-ice stream landform assemblage represented by the Summer Isles to Sula Sgeir Fan key area).

The boundaries around each key area were drawn to capture the main features or assemblages of features for which the area was prioritised. The accuracy with which this was achieved is variable and constrained by the extent and detail of existing surveys. In a number of cases, this is a significant information gap. The focus on the MPA process and context and the emphasis on seabed features means that not all locations of scientific importance are included (e.g. sub-seabed sedimentary sequences and bedrock interests). It is also probable that future seabed mapping will reveal additional geodiversity interests of high scientific importance, and that additional geodiversity interests with important biodiversity support functions may emerge in due course. Hence the list of key areas needs to be kept under review.

Most of the key areas qualify under guideline 1a (Table 1). None are presently considered to be under specific threat (guideline 1b, Table 1). A few (the carbonate production areas) are known in general terms to have functional significance, particularly in 
the context of coastal machair habitats (guideline 1c, Table 1). The functional roles of other areas in terms of supporting biodiversity remain to be established but it would be surprising if many habitats and species were not highly dependent on the abiotic characteristics and landforms of the seafloor, as they are on land.

\section{Scotland's marine geodiversity: possible threats and sensitivity}

Human activities and development in the marine environment have the potential to impact upon geodiversity interests at the seabed and the services they provide (Brooks et al., 2009; Defra, 2010; Baxter et al., 2011). They include fishing, aggregate extraction, hydrocarbon exploration, renewable energy installations, cables and pipelines, navigational dredging, dredge waste disposal and military activity. As well as direct impacts, these activities have the ability to cause near and potentially far-field effects through the interruption of existing sediment transport pathways and hydrodynamic processes. The sensitivities of key geodiversity interests to these pressures should be considered as part of marine conservation, and the requirements for protection addressed through appropriate management. As discussed below, such an approach is being adopted in Scotland.

Building on the study of Brooks et al. (2009), Brooks (2013) developed a generic sensitivity assessment of the main categories of geodiversity interest to different activities in Scotland's seas. A feature that is considered to be sensitive is one that is readily affected adversely by external factors (pressures) arising from human activities, and is expected to recover only over a very long time period, or not at all. The generic sensitivity assessment for different categories of geodiversity interest takes into account sediment type or geology (resistance) and the ability of the interest to recover from degradation (resilience) (Brooks, 2013). Features comprising soft, unconsolidated material (e.g. sand waves) are likely to be far more susceptible to a pressure than features cut into bedrock (e.g. glacial troughs). Features with low resistance and low resilience are likely to be highly sensitive and vice-versa. For example, as a general rule, relict sediment bedforms are likely to have a comparatively high sensitivity because they were formed by processes that are no longer active (e.g. glaciation), and if damaged or destroyed, cannot be re-created. Large-scale erosional glacigenic features are likely to have high resistance and low sensitivity because of their scale and formation in bedrock. Active sediment bed forms such as sand banks and sand waves have a low resistance but may have a high resilience since they are (potentially) able in the longer term to recover from impacts, providing that the formative processes and sediment supply are maintained.

An indicative sensitivity assessment shows that just under half of the feature interests of the key areas have a low generic sensitivity to the pressures arising from current human activities (Table 5). This is because although most of the interests are relict (thereby having either low or no resilience), many have high resistance to pressures since they are typically composed of resistant materials that have a low susceptibility to modification. Conversely, just over half are potentially sensitive to one or more pressures. However, further analysis was required to enable a downscaled application at a site-specific level, in the context of the MPA Selection Guidelines, to define the sensitivity of individual key areas and the risk of significant damage to their constituent interests by human activities (where the resolution of available mapping permitted). This analysis showed that, in the vast majority of instances, pressures associated with existing anthropogenic activities within the Nature Conservation MPAs were not considered likely to impact significantly on the geodiversity features present 
(primarily related to the types of existing pressures and the scale of the features); and in the cases where they did, the geodiversity features mostly overlapped directly with biodiversity interests for which appropriate management was being considered (Marine Scotland, 2013). This was judged appropriate to also achieve favourable condition of the geodiversity features within the MPAs (e.g. where iceberg ploughmarks directly overlap with sedimentary habitat protected features in the Faroe-Shetland Sponge Belt Nature Conservation MPA).

\section{Assessment of the MPA process and existing Marine Protected Areas as a mechanism for marine geoconservation}

In total, 33 Nature Conservation MPA proposals and 4 MPA search locations were identified that could contribute to the MPA network in Scotland's seas and as part of the wider UK contribution to the OSPAR North-East Atlantic MPA network (Scottish Natural Heritage and the Joint Nature Conservation Committee, 2012). Of the 33 original Nature Conservation proposals, 30 were designated on 7 August 2014; 17 fall within Scottish territorial waters under the Marine (Scotland) Act 2010 and 13 within offshore waters under the Marine and Coastal Access Act 2009 (Fig. 2). Scottish Natural Heritage submitted further formal advice in 2014 recommending the designation of 4 MPA proposals developed from the 4 initial search locations following the completion of additional research (Scottish Natural Heritage, 2014). Examples of most, if not all, of the individual interests identified in Table 2, or parts of them, present in Scottish waters are included within the designated Nature Conservation MPAs and existing protected areas (Table 6). If accepted, the 4 MPA proposals would enhance this coverage ${ }^{1}$. However, as noted above, in assessing the MPA process as a mechanism for marine geoconservation, it is important to bear in mind that it is the assemblages of interests and the interpretations placed upon them that to a significant degree determine the national and international scientific importance of the geodiversity key areas in Scottish waters, not simply the representation of individual feature interests.

Of the Nature Conservation MPAs, three fully include geodiversity key areas (Table 6): North-east Faroe Shetland Channel (Miller Slide, The Pilot Whale Diapirs), Rosemary Bank Seamount (Rosemary Bank Seamount) and Geikie Slide and Hebridean Slope (Geikie Slide). North-east Faroe Shetland Channel includes at least $75 \%$ by area of the North Sea Fan, while three others include more partial overlaps (25-75\%) with other key areas: Firth of Forth Banks Complex (Wee Bankie), The Barra Fan and Hebrides Terrace Seamount (The Barra Fan) and Loch Sunart to Sound of Jura together with Loch Creran (Loch Linnhe and Loch Etive) (Fig. 2). Although Wester Ross includes $<25 \%$ of the Summer Isles part of the Summer Isles to Sula Sgeir Fan key area, it does contain a particularly important part of this area. In the case of all these Nature Conservation MPAs, the presence of the geodiversity features provides significant additional scientific justification for their selection. Other existing protected areas (SACs, SPAs and areas with existing fisheries restrictions in place) incorporate all, or a significant $(>75 \%)$ part of seven key areas, some of which overlap with the Nature Conservation MPAs (Table 6; Fig. 2), although the geodiversity interests are not notified features.

In terms of coverage of geodiversity features within the Nature Conservation MPAs and existing protected areas, the breakdown by thematic block is variable as outlined below.

\footnotetext{
${ }^{1}$ At the time of writing in July 2016, a decision is awaited on whether these will proceed to public consultation.
} 


\subsection{Quaternary of Scotland}

Examples of individual Quaternary of Scotland interests are relatively well represented in the MPAs, although in all cases the spatial coverage of the key areas is only partial (Table 6). In terms of scientific importance, they are best represented in North-east Faroe Shetland Channel (North Sea Fan), Firth of Forth Banks Complex (Wee Bankie) Loch Sunart to Sound of Jura together with Loch Creran (Loch Linnhe and Loch Etive), The Barra Fan and Hebrides Terrace Seamount (The Barra Fan) and The Southern Trench MPA proposal (The Southern Trench). Together, these areas incorporate key individual elements of the footprint of the last British-Irish Ice Sheet and its associated landforms and deposits, including icestream lineations, ice-sheet limit moraines, trough-mouth fans, recessional moraines, iceberg ploughmarks, debris flow deposits and channels and tunnel valleys. Notwithstanding this, however, the MPA boundaries cut across the landform assemblages in the geodiversity key areas. Consequently, integral parts of the interests are not included. Existing Fisheries restriction areas, however, overlap wholly with Wee Bankie and Bosies Bank and partially with the Southern Trench which is wholly included within the Southern Trench MPA proposal if it proceeds.

\subsection{Submarine Mass Movement}

Submarine Mass Movement interests are fully incorporated in the North-east Faroe Shetland Channel MPA (Miller Slide) and Geikie Slide and Hebridean Slope MPA (Geikie Slide) (Table 6). A small part of the Peach Slide Complex lies within The Barra Fan and Hebrides Terrace Seamount MPA. The Afen and Palaeo-Afen Slides are not included within any MPA or existing protected areas.

\subsection{Marine Geomorphology of the Scottish Deep-Ocean Seabed}

Marine Geomorphology of the Scottish Deep-Ocean Seabed interests are covered by several MPAs (Table 6) - the Rosemary Bank Seamount (Rosemary Bank) and the FaroeShetland Sponge Belt (West Shetland Margin Contourite Deposits) - and existing protected areas - North-west Rockall Bank cSAC (candidate SAC) and East Rockall Bank cSAC (North-East Rockall Bank and adjacent sea floor) and Hatton Bank cSAC (Central Hatton Bank and adjacent sea floor). The only key area not covered is George Bligh Bank.

\subsection{Seabed Fluid and Gas Seep}

The two key areas for Seabed Fluid and Gas Seep interests are not included within the Nature Conservation MPAs (Table 6). However, the Darwin Mounds are fully within the Darwin Mounds SAC, and 50\% of the Scanner-Scotia-Challenger Pockmark Complex could be considered adequately protected by the Scanner Pockmark SAC.

\subsection{Cenozoic Structures of the Atlantic Margin}

Cenozoic Structures of the Atlantic Margin interests are fully covered in North-east Faroe-Shetland Channel (Pilot Whale Diapirs) and to a significant extent in Anton Dohrn Seamount cSAC and Fisheries Area (Anton Dohrn) (Table 6).

\subsection{Marine Geomorphology of the Scottish Shelf Seabed}

Marine Geomorphology of the Scottish Shelf Seabed interests are not well represented (Table 6). The Sandy Riddle Bank is not included, and the dynamic landforms and processes in the Fair Isle Strait Marine Process Bedforms are poorly represented in the MPA suite. The important and extensive shelf carbonate production areas of Shetland, Orkney and the Outer Hebrides are also poorly represented both in the Nature Conservation MPAs and existing 
protected areas, although more of the Inner Hebrides Carbonate Production area lies within the Sea of Hebrides MPA proposal (Table 6).

\subsection{Coastal Geomorphology of Scotland}

Coastal Geomorphology of Scotland interests are represented in existing protected areas in the St Kilda World Heritage Site and SAC (St Kilda Archipelago Submerged Landforms), but the North Rona and Sula Sgeir SPA includes only a small part of the Sula Sgeir submerged platforms (Table 6).

\subsection{Biogenic Structures of the Scottish Seabed}

Biogenic Structures of the Scottish Seabed interests are mainly covered by existing protected areas: Hatton Bank cSAC and Fisheries Area entirely contains Hatton Bank Carbonate Mounds, and East Mingulay cSAC entirely contains Mingulay Reef (Table 6). The East Rockall Bank cSAC covers a significant part of the Rockall Bank Biogenic Sediment Mounds.

\subsection{Overview}

Overall, therefore, while examples of most individual landforms are represented within the MPA network in Scotland's seas, there are some significant key area omissions or only partial inclusions. These relate particularly to the Quaternary of Scotland, Submarine Mass Movement and Marine Geomorphology of the Scottish Shelf Seabed features where the significance of landform assemblages and their integrity is not fully recognised.

From the sensitivity analysis of Brooks (2013), it is most likely that all the features occurring outwith the Nature Conservation MPAs but within existing SACs and other areabased designations can be considered protected by virtue of the management in place or the management that is planned to be put in place, although some cross-checking is required to verify this. More widely, however, there remains a need to understand better and quantify the risks to the key features outwith MPAs and the other designation types. This is a prerequisite to exploring conservation options, where needed, but without necessarily assuming MPAs are the only solution since there would need to be a change in Nature Conservation MPA policy implementation to enable a lead role for geodiversity interests in the site identification and designation process. In reality, a further round of site designations for geodiversity interests in their own right is unlikely at this time and certainly not without a compelling case in terms of their ecosystem functional role. Similarly, there is no mechanism to formally encompass geodiversity interests within the other existing designation types (SACs and SPAs) away from the coast. Due consideration under marine planning as part of the broader 'three-pillar' approach to effective marine nature conservation in Scotland, which includes species measures, site protection measures and wider seas policies and measures (Marine Scotland, 2011a), probably offers the best approach since the hooks for planning advice to take account of key geodiversity interests now exist in Scotland's National Marine Plan (Scottish Government, 2015). The latter includes the stated policy that "marine planning should consider opportunities to protect important geodiversity features and prevent deterioration or enhance where appropriate" (para 4.60). These features should be viewed as being equivalent to Priority Marine Features (PMFs) (Howson et al., 2012) (in the same way as these features played a role in the MPA identification process comparable to MPA search features for biodiversity interests). However, at the current time the geodiversity key areas and the underpinning feature data are available in a static format only (Brooks et al., 2013). To facilitate the process of better integration of geodiversity interests in marine planning, 
relevant data need to be mobilised to National Marine Plan interactive (NMPi) geospatial layers and promoted and supported by the development of interpretive guidance for decision makers.

\section{Conclusions}

1. Scotland's territorial and offshore waters contain geodiversity features of national and international scientific importance for a range of interests representing the evolution of the NW European continental margin, the dynamics of marine-based ice sheets and their coupling with climate and ocean circulation patterns, and past and present marine and coastal processes. These interests are also significant in providing ecosystem services and benefits, including seabed habitats for marine life and the basis for offshore energy development (oil, gas and renewables), offshore aggregates, fisheries and natural sinks for blue carbon.

2. As part of a wider study of the characterisation of Scotland's territorial and offshore waters, 35 key areas have been selected to represent eight categories of nationally and internationally important geodiversity features on the seafloor. Many of these areas have multiple interests. Together with detailed information on marine wildlife and habitats, the geodiversity information has been used to advise Scottish Government and others on marine conservation and development, including international commitments to create a network of MPAs (Scottish Natural Heritage and the Joint Nature Conservation Committee, 2012; Scottish Natural Heritage, 2014).

3. Of the eight geodiversity thematic blocks, the interests of five are reasonably well represented within the suite of MPAs and other area-based protection measures in Scotland's seas. In the three other cases, Quaternary of Scotland, Submarine Mass Movement and Marine Geomorphology of the Scottish Shelf Seabed, the coverage is more limited. In total, 14 of the 35 geodiversity key areas are significantly incorporated (>75\% by area) within Nature Conservation MPAs, MPA proposals and other existing protected areas. Overall, therefore, and bearing in mind the supporting role accorded to geodiversity in the Scottish MPA implementation policy, geodiversity may be considered moderately well accommodated within the MPA network, at least in terms of individual interests. The MPA process has also been moderately successful in developing an integrated approach, since the presence of geodiversity features provides significant additional scientific justification that was taken into account during the assessment of MPA search locations and the final selection of 18 of the 30 Nature Conservation MPAs and all 4 of the current MPA proposals (Scottish Natural Heritage, 2014).

4. By way of qualification, however, the spatial coverage of geodiversity interests in the Nature Conservation MPAs and other existing protected areas falls short in terms of incorporating integral landform assemblages; in many cases such assemblages are only partly included although their integrity overall is more important than the individual landforms. Furthermore, the extent to which the MPA process will succeed in meeting the needs of geoconservation by affording protection to these interests still remains to be fully determined. The interests of 18 of the geodiversity key areas are recognised as protected features in the Nature Conservation MPAs and should therefore be afforded protection within the latter. The interests of those areas that overlap spatially with other types of existing protected area are not designated as such but will probably be protected 
by default through biodiversity related management measures to protect the integrity of seafloor habitats and species, as will those that are not recognised as features of interest within the MPAs (Table 6). This should be verified by a sensitivity analysis (see below) and, if required, by an assessment of overlaps of activities with the key areas, potential impacts and the need for monitoring where appropriate and practical.

5. The interests in the geodiversity key areas range from large-scale landforms (submarine landslides and trenches) to small-scale dynamic features (sand waves). Consequently, they will have a range of sensitivities to different pressures and hence different conservation management requirements. Management options have been developed for each of the Nature Conservation MPAs and, where needed, new measures are starting to be implemented (Marine Scotland, 2016). An additional step to identify the sensitivities, vulnerabilities and management requirements for each of the geodiversity key areas should determine the most appropriate strategies in the context of the 'three-pillar' approach to effective marine nature conservation in Scotland (Marine Scotland, 2011a) and also inform the development of guidance for policy and planning leads. Specific assessment of the sensitivities and management requirements is required for the full extents of the geodiversity key areas in order to help prioritise any future actions in relation to the omissions and partial coverage of landform assemblages. A further requirement is to evaluate the extent to which marine planning might address the conservation and management needs of the features in the key areas where not afforded protection by the MPA network. There is clearly more to be done to raise their profile in comparison with PMFs and to clarify how they should be viewed in the context of marine planning, together with incorporation of relevant data in NMPi and the development of guidance for decision makers. Given the importance of the Shelf Carbonate Production Areas as a source of shell sand for the internationally important machair habitats and their limited representation within the MPA suite, research is required to identify any particularly critical areas within the present extensive boundaries of the geodiversity key areas that require specific conservation management.

6. Since it is probable that additional geodiversity key areas will be identified as the results of further seabed survey and mapping become available (e.g. from the BRITICECHRONO project: http://www.britice-chrono.group.shef.ac.uk/), the geoconservation assessment should be kept under review and updated periodically. Also, the specific management of additional geodiversity interests and areas with important functions for biodiversity support, including climate change resilience, and blue carbon sequestration may need to be addressed in due course.

7. A further priority is research to establish the extent to which the existing Coastal Geomorphology GCR sites depend on processes outside the existing terrestrial site boundaries and hence require possible nearshore extensions.

8. As part of a more integrated approach, systematic survey and assessment of the role of geodiversity in supporting marine life and providing a diversity of habitats at a sitespecific scale would offer new insights into the functional links between marine geodiversity and biodiversity and provide a basis for informing marine planning and further integration of geodiversity within an ecosystem approach that recognises whole site integrity (Hopkins et al., 2016). This could usefully build on the MAREMAP initiative (Howe et al., 2015a), application of the Norwegian 'nature areas' mapping type of approach in the marine environment (Dolan et al., 2009; Thorsnes et al., 2009; Buhl- 
Mortensen et al., 2015b) or other forms of seabed biophysical characterisation (Harris and Baker, 2012). In addition, as in the terrestrial environment (Anderson and Ferree, 2010; Beier et al., 2015; Theobald et al., 2015), an approach that recognises the potential value of 'conserving nature's stage' in MPA network design could help to enhance ecosystem resilience in the face of climate change, which is recognised as an important objective and challenge for marine conservation planning (Hopkins et al., 2016). Also in relation to climate change, the importance of protecting natural sinks for blue carbon in marine sediments (Scottish Government, 2015; Hopkins et al., 2016) offers further opportunities to integrate geodiversity and geoconservation.

9. Finally, the approach to marine geoconservation that is emerging in Scotland is a pragmatic one. Given the real practical difficulties in managing and monitoring most key areas because of their remoteness and location on the seabed and the resources required, combined with the benefits in developing an ecosystem approach, it makes sound sense to align the conservation of geodiversity and geoheritage with the conservation of biodiversity as far as possible through integrated management and monitoring of protected areas, and elsewhere for stand-alone measures for geoconservation to be based on evidence of the sensitivity and vulnerability of the interests.

\section{Acknowledgements}

This study was part-funded by Marine Scotland and was undertaken as part of the Scottish Marine Protected Areas (MPA) Programme, a joint initiative between Marine Scotland, Historic Scotland, Scottish Natural Heritage (SNH) and the Joint Nature Conservation Committee (JNCC). We thank the participants at the Edinburgh workshop in February 2010 for insightful discussion on the assessment of the geodiversity key areas, and two anonymous reviewers for helpful comments that improved the manuscript. DL publishes with permission of the Executive Director of the British Geological Survey (NERC).

\section{References}

Akhmetzhanov, A., Kenyon, N.H., Habgood, E., van der Mollen, A.S., Nielsen, T., Ivanov, M., Shashkin, P., 2007. North Atlantic contourite sand channels. In: Viana, A.R., Rebesco, M. (Eds.), Economic and Palaeoceanographic Significance of Contourite Deposits. The Geological Society, London, Special Publications 276, pp. 25-47.

Anderson, M.G., Ferree, C.E., 2010. Conserving the stage: climate change and the geophysical underpinnings of species diversity. PLoS ONE 5(7): e11554.doi:10.1371/journal.pone.0011554.

Angus, S., 1994. The conservation importance of machair systems of the Scottish Islands, with particular reference to the Outer Hebrides. In: Baxter, J.M., Usher, M.B. (Eds.), The Islands of Scotland. A Living Marine Heritage. HMSO, Edinburgh, pp. 95-120.

Audsley, A., Arosio, R., Howe, J.A., 2016. A geomorphological reconstruction of the deglaciation of Loch Etive during the Loch Lomond Stadial. Scottish Journal of Geology 52, 55-63.

Austin, W.E.N., Kroon, D., 2001. Deep sea ventilation of the northeastern Atlantic during the last 15,000 years. Global and Planetary Change 30, 13-31. 
Austin, W.E.N., Hibbert, F.D., Rasmussen, S.O., Peters, C., Abbott, P.M., Bryant, C.L., 2012. The synchronization of palaeoclimatic events in the North Atlantic region during Greenland Stadial 3 (ca 27.5 to 23.3 kyr b2k). Quaternary Science Reviews 36, 154163.

Baltzer, A., Bates, R., Mokeddem, Z., Clet-Pellerin, M., Walter-Simonnet, A-V., BonnotCourtois, C., Austin, W.E.N., 2010. Using seismic facies and pollen analyses to evaluate climatically driven change in a Scottish sea loch (fjord) over the last $20 \mathrm{ka}$. In: Howe, J.A., Austin, W.E.N., Forwick, M., Paetzel, M. (Eds.), Fjord Systems and Archives. Geological Society, London, Special Publications 344, pp. 355-369.

Baxter, J.M., Boyd, I.L., Cox, M., Donald, A.E., Malcolm, S.J., Miles, H., Miller, B., Moffat, C.F. (Eds.), 2011. Scotland's Marine Atlas: Information for the National Marine Plan. Marine Scotland, Edinburgh.

Beier, P., Hunter, M.L., Anderson, M.G., 2015. Special section: conserving nature's stage. Conservation Biology 29, 613-617.

Belderson, R.H., Kenyon, N.H., Wilson, J.B., 1973. Iceberg plough marks in the northeast Atlantic. Palaeogeography, Palaeoclimatology, Palaeoecology 13, 215-224.

Belderson, R.H., Johnson, M.A., Kenyon, N.H., 1982. Bedforms. In: Stride, A.H. (Ed.), Offshore Tidal Sands: Processes and Products. Chapman \& Hall, London, pp. 27-57.

Bell, B.R., Williamson, I.T., 2002. Tertiary igneous activity. In: Trewin, N.H. (Ed.), The Geology of Scotland. The Geological Society, London, pp. 371-407.

Bondevik, S., Mangerud, J., Dawson, S., Dawson, A., Lohne, Ø., 2005. Evidence for three North Sea tsunamis at the Shetland Islands between 8000 and 1500 years ago. Quaternary Science Reviews 24, 1757-1775.

Bowen, D.Q., Philips, F.M., McCabe, A.M., Knutz, P.C., Sykes, G.A., 2002. New data for the Last Glacial Maximum in Great Britain and Ireland. Quaternary Science Reviews 21, 89-101.

Boulton, G.S., Hagdorn, M., 2006. Glaciology of the British Isles Ice Sheet during the last glacial cycle: form, flow, streams and lobes. Quaternary Science Reviews 25, 3359-3390.

Bradley, S.L., Milne, G.A., Shennan, I., Edwards, R., 2011. An improved glacial isostatic adjustment model for the British Isles. Journal of Quaternary Science 26, 541-552.

Bradwell, T., Stoker, M. 2015. Asymmetric ice-sheet retreat pattern around northern Scotland revealed by marine geophysical surveys. Earth and Environmental Science Transactions of the Royal Society of Edinburgh 105, 297-322.

Bradwell, T., Stoker, M., Larter, R., 2007. Geomorphological signature and flow dynamics of The Minch palaeo-ice stream, northwest Scotland. Journal of Quaternary Science 22, 609-617.

Bradwell, T., Stoker, M.S., Golledge, N.R., Wilson, C.K., Merritt, J.W., Long, D., Everest, J.D., Hestvik, O.B., Stevenson, A.G., Hubbard, A.L., Finlayson, A.G., Mathers, H.E., 2008a. The northern sector of the last British Ice Sheet: maximum extent and demise. Earth-Science Reviews 88, 207-226.

Bradwell, T., Stoker, M., Krabbendam, M., 2008b. Megagrooves and streamlined bedrock in NW Scotland: the role of ice streams in landscape evolution. Geomorphology 97, 135156. 
Brooks, A.J., 2013. Assessing the sensitivity of geodiversity features in Scotland's seas to pressures associated with human activities. Scottish Natural Heritage Commissioned Report No. 590. Available at:

$<$ http://www.snh.org.uk/pdfs/publications/commissioned reports/590.pdf $>$ [Accessed on 25 July, 2016].

Brooks, A.J., Roberts, H., Kenyon, N.H., Houghton, A.J., 2009. Assessing and developing the required biophysical datasets and datalayers for Marine Protected Areas network planning and wider marine spatial planning purposes. Report No.8 Task 2A. Project code: MB102, Marine Biodiversity R\&D Programme. Contract administered by Defra. Defra, London. Available at: $<$ http://randd.defra.gov.uk/Default.aspx?Menu=Menu\&Module=More \&Location=None \&Completed $=0 \&$ ProjectID $=16368>$ [Accessed on 25 July, 2016].

Brooks, A.J., Kenyon, N.H., Leslie, A., Long, D., Gordon, J.E., 2013. Characterising Scotland's marine environment to define search locations for new Marine Protected Areas. Part 2: The identification of key geodiversity areas in Scottish Waters. Scottish Natural Heritage Commissioned Report No. 432. Available at: $<$ http://www.snh.org.uk/pdfs/publications/commissioned reports/432.pdf $>$ [Accessed on 25 July, 2016].

Buhl-Mortensen, L., Buhl-Mortensen, P., Dolan, M.F.J., Gonzalez-Mirelis, G., 2015a. Habitat mapping as a tool for conservation and sustainable use of marine resources: Some perspectives from the MAREANO Programme, Norway. Journal of Sea Research $100,46-61$.

Buhl-Mortensen, L., Buhl-Mortensen, P., Dolan, M.F.J., Holte, B., 2015b. The MAREANO programme - A full coverage mapping of the Norwegian off-shore benthic environment and fauna. Marine Biology Research 11, 4-17.

Burek, C.V., Ellis, N.V., Evans, D.H., Hart, M.B., Larwood, J.G., 2013. Marine geoconservation in the United Kingdom. Proceedings of the Geologists' Association 124, 581-592.

Burrows, M.T., Kamenos, N.A., Hughes, D.J., Stahl, H., Howe, J.A., Tet, P., 2014. Assessment of carbon budgets and potential blue carbon stores in Scotland's coastal and marine environment. Scottish Natural Heritage Commissioned Report No. 761. Available at: < http://www.snh.org.uk/pdfs/publications/commissioned_reports/761.pdf> [Accessed on 25 July, 2016].

Cage, A.G., Austin, W.E.N., 2010. Marine climate variability during the last millennium: the Loch Sunart record, Scotland, UK. Quaternary Science Reviews 29, 1633-1647.

Callaway, A., Quinn, R., Brown, C.J., Service, M., Long, D., Benetti, S., 2011. The formation and evolution of an isolated submarine valley in the North Channel, Irish Sea: an investigation of Beaufort's Dyke. Journal of Quaternary Science 26, 362-373.

Chiocci, F.L., Chivas, A.R., 2014. Continental Shelves of the World: Their Evolution During the Last Glacio-Eustatic Cycle. The Geological Society, London, Memoirs, 41.

Chiverrell, R.C., Thomas, G.S.P., 2010. Extent and timing of the Last Glacial Maximum (LGM) in Britain and Ireland: a review. Journal of Quaternary Science 25, 535-549.

Clark, C.D., Hughes, A.L.C., Greenwood, S.L., Jordan, C., Sejrup, H.P., 2012. Pattern and timing of retreat of the last British-Irish Ice Sheet. Quaternary Science Reviews 44, 112146. 
Convention on Biological Diversity, 1992. Convention on Biological Diversity. United Nations. Available at: <https://www.cbd.int/convention/> [Accessed on 25 July, 2016].

Cooper, R.G., 2007. Mass Movements in Great Britain. Geological Conservation Review Series No. 26. Joint Nature Conservation Committee, Peterborough.

Cundill, P.R., Austin, W.E.N., 2010. Pollen analysis of Holocene sediments from Loch Etive, a Scottish fjord. In: Howe, J.A., Austin, W.E.N., Forwick, M., Paetzel, M. (Eds.), Fjord Systems and Archives. The Geological Society, London, Special Publications 344, pp. 331-340.

Dahlgren, K.I.T., Vorren, T.O., Stoker, M.S., Nielsen, T., Nygård, A., Sejrup. H.P., 2005. Late Cenozoic prograding wedges on the NW European continental margin: their formation and relationship to tectonics and climate. Marine and Petroleum Geology 22, 1089-1110.

Davies, A.J., Green, S.L., Long, D., Roberts, J.M., 2009. Developing the necessary data layers to inform the development of a site boundary for the East Mingulay dSAC - Phase II. Scottish Natural Heritage Commissioned Report No. 306. Available at:

$<$ http://www.snh.org.uk/pdfs/publications/commissioned reports/306.pdf $>$ [Accessed on 25 July, 2016].

Dawson, A.G., Dawson, S., Mighall, T.N., Waldmann, G., Brown, A., Mactaggart, F., 2001. Intertidal peat deposits and early Holocene relative sea-level changes, Traigh Eileraig, Isle of Coll, Scottish Hebrides. Scottish Journal of Geology 37, 11-18.

Dawson, A.G., Bondevik, S., Teller, J.T., 2011. Relative timing of the Storegga submarine slide, methane release, and climate change during the 8.2 ka cold event. The Holocene 21, 1167-1171.

Defra, 2010. Charting Progress 2. The State of UK Seas. Defra, London. Available at: $<$ http://chartingprogress.defra.gov.uk $>$ [Accessed on 25 July, 2016].

Dickson, A.J., Austin, W.E.N., Hall, I.R., Maslin, M.A., Kucera, M., 2008. Centennial-scale evolution of Dansgaard-Oeschger events in the northeast Atlantic Ocean between 39.5 and 56.5 ka B.P. Paleoceanography 23, PA3206, doi:10.1029/2008PA001595.

Diesing, M., Green, S.L., Stephens, D., Lark, R.M., Stewart, H., Dove, D., 2014. Mapping seabed sediments: Comparison of manual, geostatistical, object-based image analysis and machine learning approaches. Continental Shelf Research 84, 107-119.

Dolan, M.F.J., Buhl-Mortensen, P., Thorsnes, T., Buhl-Mortensen, L., Bellec, V., Bøe, R., 2009. Developing seabed nature-type maps offshore Norway: initial results from the MAREANO programme. Norwegian Journal of Geology 89, 17-28.

Dove, D., Arosio, R., Finlayson, A., Bradwell, T., Howe, J.A., 2015. Submarine glacial landforms record Late Pleistocene ice-sheet dynamics, Inner Hebrides, Scotland. Quaternary Science Reviews 123, 76-90.

Dowdeswell, J.A., Canals, M., Jakobsson, M., Todd, B.J., Dowdeswell, E.K., Hogan, K.A. (eds), 2016. Atlas of Submarine Glacial Landforms: Modern, Quaternary and Ancient. The Geological Society, London, Memoirs, 46.

Dunlop, P., Shannon, R., McCabe, M., Quinn, R., Doyle, E., 2010. Marine geophysical evidence for ice sheet extension and recession on the Malin Shelf: New evidence for the western limits of the British Irish Ice Sheet. Marine Geology 276, 86-99. 
Edwards, J.W.F., 2002. Development of the Hatton-Rockall Basin, North East Atlantic Ocean. Marine and Petroleum Geology 19, 193-205.

Elliott, G.M., Parson, L.M., 2008. Influence of sediment drift accumulation on the passage of gravity driven sediment flows in the Iceland basin, NE Atlantic. Marine and Petroleum Geology 25, 219-233.

Ellis, N., 2011. The Geological Conservation Review (GCR) in Great Britain - rationale and methods. Proceedings of the Geologists' Association 122, 353-362.

Ellis, N.V., Bowen, D.Q., Campbell, S., Knill, J.L., McKirdy, A.P., Prosser, C.D., Vincent, M.A., Wilson, R.C.L., 1996. An Introduction to the Geological Conservation Review. Joint Nature Conservation Committee, Peterborough.

Emeleus, C.H., Bell, B.R., 2005. British Regional Geology: the Palaeogene Volcanic Districts of Scotland. (Fourth edition). British Geological Survey, Nottingham.

European Commission, 2011. Our Life Insurance, Our Natural Capital: An EU Biodiversity Strategy to 2020. COM(2011) 244 final. European Commission, Brussels. Available at: $<$ http://ec.europa.eu/environment/nature/biodiversity/comm2006/2020.htm $>$ [Accessed on 25 July, 2016].

Evans, D., 1997. A History of Nature Conservation in Britain. $2^{\text {nd }}$ edition. Routledge, London.

Evans, D., Harrison, Z., Shannon, P.M., Laberg, J.S., Nielsen, T., Ayers, S., Holmes, R., Houlta, R.J., Lindberg, B., Haflidason, H., Long, D., Kuijpers, A., Andersen, E.S., Bryn, P., 2005. Palaeoslides and other mass failures of Pliocene to Pleistocene age along the Atlantic continental margin of NW Europe. Marine and Petroleum Geology 22, 11311148.

Evans, D.J.A., Clark, C.D., Mitchell, W.A., 2005. The last British Ice Sheet: a review of the evidence utilised in the compilation of the Glacial Map of Britain. Earth-Science Reviews 70, 253-312.

Finlayson, A., Merritt, J., Auton, C., Graham, A., Bradwell, T., Stoker, M., Golledge, N., Everest, J., 2008. Dynamics and disintegration of the Moray Firth palaeo-ice stream. In: Bridgland, D.R., Golledge, N.R., Silva, B.N. (Eds.), Quaternary of the British Isles and Adjoining Seas. Abstracts for Quaternary Research Association Annual Discussion Meeting, January 8-10, 2008. Quaternary Research Association, London, p. 49.

Furze, M.F.A., Roberts, M.J., 2004. Assessing the Conservation Value of Geological Sites in the Marine Environment: Numerical Assessment of Candidate Sites. Unpublished Report prepared for the Joint Nature Conservation Committee by the Centre for Applied Oceanography, School of Ocean Sciences, University of Wales, Bangor, Contract Number: F90-01-665. University of Wales, Bangor. Available at: $<$ http://jncc.defra.gov.uk/pdf/isp_feasibility_followup_withoutapp.pdf $>$ [Accessed on 25 July, 2016].

Gafeira, J., Long, D., 2015. Geological investigation of pockmarks in the Scanner Pockmark SCI area. JNCC Report No 570. Joint Nature Conservation Committee, Peterborough. Available at: <http://jncc.defra.gov.uk/pdf/570_web.pdf> [Accessed on 25 July, 2016].

Golledge, M.R., Stoker, M.S., 2006. A palaeo-ice stream of the British Ice Sheet in eastern Scotland. Boreas 35, 231-243. 
Gordon, J.E., Barron, H.F., 2013. Geodiversity and ecosystem services in Scotland. Scottish Journal of Geology 49, 41-58.

Gordon, J.E., Sutherland, D.G., 1993. Quaternary of Scotland. Geological Conservation Review Series No. 6. Chapman \& Hall, London.

Gordon, J.E., Barron, H.F., Hansom, J.D., Thomas, M.F., 2012. Engaging with geodiversity why it matters. Proceedings of the Geologists' Association 123, 1-6.

Gordon, J.E., Brooks, A.J., Rennie, A.F., James, B.D., Chaniotis, P.D., Kenyon, N.H., Leslie, A.B., Long, D., 2013. The selection of Nature Conservation Marine Protected Areas (MPAs) in Scotland - assessment of geodiversity interests. Scottish Natural Heritage Commissioned Report No. 633. Available at:

$<$ http://www.snh.org.uk/pdfs/publications/commissioned_reports/633.pdf $>$ [Accessed on 25 July, 2016].

Graham, A.G.C., Lonergan, L., Stoker, M.S., 2007. Evidence for Late Pleistocene ice stream activity in the Witch Ground Basin, central North Sea, from 3D seismic reflection data. Quaternary Science Reviews 26, 627-643.

Graham, A.G.C., Lonergan, L., Stoker, M.S., 2009. Seafloor glacial features reveal the extent and decay of the last British Ice Sheet, east of Scotland. Journal of Quaternary Science 24, 117-138.

Graham, A.G.C., Lonergan, L., Stoker, M.S., 2010. Depositional environments and chronology of Late Weichselian glaciation and deglaciation in the central North Sea. Boreas 39, 471-491.

Gray, M., Gordon, J.E., Brown, E.J., 2013. Geodiversity and the ecosystem approach: the contribution of geoscience in delivering integrated environmental management. Proceedings of the Geologists' Association 124, 659-673.

Hall, A.M., Bishop, P., 2002. Scotland's denudational history: an integrated view of erosion and sedimentation at an uplifted passive margin. In: Doré, A.G., Cartwright, J.A., Stoker, M.S., Turner, J.P., White, N. (Eds.), Exhumation of the North Atlantic Margin: Timing, Mechanisms and Implications for Petroleum Exploration. The Geological Society, London, Special Publications 196, pp. 271-290.

Hall, I.R., Colmenero-Hidalgo, E., Zahn, R., Peck, V.L., Hemming S.R., 2011. Centennial- to millennial-scale ice-ocean interactions in the subpolar northeast Atlantic 18-41 kyr ago. Paleoceanography 26, PA2224, doi:10.1029/2010PA002084.

Hansom, J.D., 2003a. Machair. In: May V.J., Hansom J.D. (Eds.), Coastal Geomorphology of Great Britain. Geological Conservation Review Series 28. Joint Nature Conservation Committee, Peterborough, pp. 471-514.

Hansom J.D., 2003b. St Kilda, Western Isles. In: May, V.J., Hansom, J.D. (Eds.), Coastal Geomorphology of Great Britain. Geological Conservation Review Series No. 28. Joint Nature Conservation Committee, Peterborough, pp. 60-68.

Hansom, J.D., Angus, S., 2001. Tir a 'Mhachair (Land of the Machair): sediment supply and climate change scenarios for the future of the Outer Hebrides machair. In: Gordon, J.E., Leys, K.F. (Eds.), Earth Science and the Natural Heritage: Interactions and Integrated Management. The Stationery Office, Edinburgh, pp 68-81.

Harris, P.T., Baker, E.K. 2012. Seafloor Geomorphology as Benthic Habitat. GeoHAB Atlas of Seafloor Geomorphic Features and Benthic Habitats. Elsevier, Amsterdam. 
Harris, P.T., Macmillan-Lawler, M., Rupp, J., Baker, E.K., 2014. Geomorphology of the oceans. Marine Geology 352, 4-24.

Heap, A.D., Harris, P.T., 2011. Geological and biological mapping and characterisation of benthic marine environments - introduction to the special issue. Continental Shelf Research, 31(2) Supplement, S1-S3.

Henriques, M.H., Pena dos Reis, R., Brilha, J., Mota, T., 2011. Geoconservation as an emerging geoscience. Geoheritage 3, 117-128.

Hibbert, F., Austin, W.E.N., Leng, M.J., Gatliffe, R.W., 2010. British Ice Sheet dynamics inferred from North Atlantic ice-rafted debris records spanning the last 175000 years. Journal of Quaternary Science 25, 461-482.

Hjelstuen, B.O., Eldholm, O., Skogseid, J., 1997. Voring Plateau diapir fields and their structural and depositional settings. Marine Geology 144, 33-57.

Hohbein, M., Cartwright, J., 2006. 3D seismic analysis of the West Shetland Drift system: Implications for Late Neogene palaeoceanography of the NE Atlantic. Marine Geology 230, 1-20.

Holford, S.P., Green, P.F., Duddy, I.R., Turner, J.P., Hillis, R.R., Stoker, M.S., 2009. Regional intraplate exhumation episodes related to plate-boundary deformation. Geological Society of America Bulletin 121, 1611-1628.

Holford, S.P., Green, P.F., Hillis, R.R., Underhill, J.R., Stoker, M.S., Duddy, I.R., 2010. Multiple post-Caledonian exhumation episodes across NW Scotland revealed by apatite fission-track analysis. Journal of the Geological Society of London 167, 675-694.

Holmes, R., 1997. Quaternary stratigraphy: the offshore record. In: Gordon, J.E. (Ed.), Reflections on the Ice Age in Scotland. Scottish Association of Geography Teachers and Scottish Natural Heritage, Glasgow, pp. 72-94.

Holmes, R., Long, D., Dodd, L.R., 1998. Large-scale debrites and submarine landslides on the Barra Fan, west of Britain. In: Stoker, M.S., Evans D., Cramp A. (Eds.), Geological Processes on Continental Margins: Sedimentation, Mass Wasting and Stability. The Geological Society, London, Special Publications 129, pp. 67-79.

Holmes, R., Hobbs, P.R.N., Leslie, A.B., Wilkinson, I.P., Gregory, F.J., Riding, J.B., Hoult, R.J., Cooper, R.M., Jones, S.M., 2003. DTI Strategic Environmental Assessment Area 4 (SEA4): Geological evolution Pilot Whale Diapirs and stability of the seabed habitat. British Geological Survey Commercial Report CR/03/082. British Geological Survey, Edinburgh. Available at: $<$ https://www.gov.uk/government/uploads/system/uploads/attachment_data/file/197365/ SEA4 TR Diapirs BGS.pdf $>$ [Accessed on 25 July, 2016].

Holmes, R., Bulat, J., Henni, P., Holt, J., James, C., Kenyon, N., Leslie, A., Long, D., Musson, R., Pearson, S., Stewart, H., 2004. DTI Strategic Environmental Assessment Area 5 (SEA5): Seabed and superficial geology and processes. British Geological Survey Report CR/04/064N. British Geological Survey, Edinburgh. Available at: $<$ https://www.gov.uk/government/uploads/system/uploads/attachment data/file/197385/ SEA5_TR_Geology_BGS.pdf $>$ [Accessed on 25 July, 2016]. 
Holt, T.J., Rees, E.I., Hawkins, S.J., Seed, R., 1998. Biogenic Reefs (Volume IX). An Overview of Dynamic and Sensitivity Characteristics for Conservation Management of Marine SACs. Scottish Association for Marine Science (UK Marine SACs Project), Oban. Available at: <http://www.ukmarinesac.org.uk/pdfs/biogreef.pdf $>$ [Accessed on 25 July, 2016].

Hopkins, C.R., Bailey, D.M., Potts, T., 2016. Scotland's Marine Protected Area network: reviewing progress towards achieving commitments for marine conservation. Marine Policy 71, 44-53.

Hoppe, G., 1965. Submarine peat in the Shetland Islands. Geografiska Annaler 47A,195-203.

Howe, J.A., Harland, R., Hine, N.M., Austin, W.E.N., 1998. Late Quaternary stratigraphy and palaeoceanographic change in the northern Rockall Trough, North Atlantic Ocean. In: Stoker, M.S., Evans, D., Cramp A. (Eds.), Geological Processes on Continental Margins: Sedimentation, Mass-Wasting and Stability. The Geological Society, London, Special Publications 129, pp. 269-286.

Howe, J.A., Shimmield, T., Austin, W.E.N., Longva, O., 2002. Post-glacial depositional environments in a mid-high latitude glacially-overdeepened sea loch, inner Loch Etive, western Scotland. Marine Geology 185, 417-433.

Howe, J.A., Dove, D., Bradwell, T., Gafeira, J., 2012. Submarine geomorphology and glacial history of the Sea of the Hebrides, UK. Marine Geology 315-318, 64-76.

Howe, J.A., Stevenson, A., Gatliff, R., 2015a. Seabed mapping for the 21st century - the Marine Environmental Mapping Programme (MAREMAP): preface. Earth and Environmental Science Transactions of the Royal Society of Edinburgh 105, 239-240.

Howe, J.A., Anderton, R., Arosio, R., Dove, D., Bradwell, T., Crump, P., Cooper, R., Cocuccio, A., 2015b. The seabed geomorphology and geological structure of the Firth of Lorn, western Scotland, UK, as revealed by multibeam echo-sounder survey. Earth and Environmental Science Transactions of the Royal Society of Edinburgh 105, 273-284.

Howson, C., Steel, L., Carruthers, M., Gillham, K., 2012. Identification of Priority Marine Features in Scottish Territorial Waters. Scottish Natural Heritage Commissioned Report No. 388. Available at: $<$ http://www.snh.org.uk/pdfs/publications/commissioned_reports/388.pdf $>$ [Accessed on 25 July, 2016]

Hubbard, A., Bradwell, T., Golledge, N., Hall, A., Patton, H., Sugden, D., Cooper, R., Stoker, M., 2009. Dynamic cycles, ice streams and their impact on the extent, chronology and deglaciation of the British-Irish ice sheet. Quaternary Science Reviews 28, 758-776.

Jacobs, C.L., 2006. An appraisal of the surface geology and sedimentary processes within SEA7, the UK continental shelf. National Oceanography Centre, Southampton Research Report No. 18. National Oceanography Centre, Southampton. Available at: $<$ http://eprints.soton.ac.uk/162181/1/NOCS_R\%26C_18.pdf $>$ [Accessed on 25 July, 2016].

Joint Nature Conservation Committee, 2008. Offshore Special Area of Conservation: Darwin Mounds SAC Selection Assessment Version 4.0. Joint Nature Conservation Committee, Peterborough. Available at: $<$ http://www.jncc.gov.uk/PDF/DarwinMounds_SelectionAssessment_4.0.pdf $>$ [Accessed on 25 July, 2011] 
Judd, A., Hovland, M., 2007. Seabed Fluid Flow: The Impact on Geology, Biology and the Marine Environment. Cambridge University Press, Cambridge.

Kenyon, N.H., Cooper, W.S., 2005. Sand banks, sand transport and offshore wind farms. DTI SEA 6 Technical Report. Department of Trade and Industry, London.

Kenyon, N.H., Pelton, C.D., 1979. Seabed conditions west of the Outer Hebrides. Institute of Oceanographic Sciences Report No. 95. Institute of Oceanographic Sciences, Wormley. Available at: $<$ http://eprints.soton.ac.uk/14378/1/14378-01.pdf $>$ [Accessed on 25 July, 2016].

Knutz, P.C., Austin, W.E.N., Jones, E.J.W., 2001. Millennial-scale depositional cycles related to British Ice Sheet variability and North Atlantic paleocirculation since $45 \mathrm{kyr}$ B.P., Barra Fan, U.K. margin. Paleoceanography 16, 53-64.

Knutz, P.C., Jones, E.J.W., Austin, W.E.N., van Weering, T.C.E., 2002.Glacimarine slope sedimentation, contourite drifts and bottom current pathways on the Barra Fan, UK North Atlantic margin. Marine Geology 188, 129-146.

Knutz, P.C., Zahn, R., Hall I.R., 2007. Centennial-scale variability of the British Ice Sheet: Implications for climate forcing and Atlantic meridional overturning circulation during the last deglaciation. Paleoceanography 22, PA1207, doi:10.1029/2006PA001298.

Kroon, D., Austin, W.E.N., Chapman, M.R., Ganssen, G.M., 1997. Deglacial surface circulation changes in the north-eastern Atlantic: temperature and salinity records off NW Scotland on a century scale. Paleoceanography 12, 755-763.

Kroon, D., Shimmield, G., Austin, W.E.N., Derrick, S., Knutz, P., Shimmield, T., 2000. Century- to millenial-scale sedimentological-geochemical records of glacial-Holocene sediment variations from the Barra Fan (NE Atlantic). Journal of the Geological Society of London 157, 643-653.

Lee, J.R., Busschers, F.S., Sejrup, H.P., 2012. Pre-Weichselian Quaternary glaciations of the British Isles, The Netherlands, Norway and adjacent marine areas south of $68^{\circ} \mathrm{N}$ : implications for long-term ice sheet development in northern Europe. Quaternary Science Reviews 44, 213-228.

Lenton, T.M., Held, H., Kriegler, E., Hall, J.W., Lucht, W., Rahmstorf, S., Schellnhuber, H.J., 2008. Tipping elements in the Earth's climate system. PNAS 105, 1786-1793.

Leynaud, D., Mienert, J., Vanneste, M., 2009. Submarine mass movements on glaciated and non-glaciated European continental margins: A review of triggering mechanisms and preconditions to failure. Marine and Petroleum Geology 26, 618-632.

Light, J.M., Wilson, J.B., 1998. Cool-water carbonate deposition on the West Shetland shelf: a modern distally steepened ramp. In: Wright, V.P., Burchette, T.P. (Eds.), Carbonate Ramps. The Geological Society, London, Special Publications 149, pp. 73-105.

Lonergan, L., Maidment, S.C.R., Collier, J.S., 2006. Pleistocene subglacial tunnel valleys in the central North Sea basin: 3-D morphology and evolution. Journal of Quaternary Science 21, 891-903.

Long, D., Stevenson, A.G., Wilson, C.K., Bulat, J., 2003. Slope failures in the Faroe Shetland Channel. In: Locat, J., Mienert, J. (Eds.), Submarine Mass Movements and their Consequences. Advances in Natural and Technological Hazards Research Series. Kluwer Academic Publishers, Dordrecht, pp. 281-289. 
Long, D., Bulat, J., Stoker, M.S., 2004. Sea bed morphology of the Faroe-Shetland Channel derived from 3D seismic datasets. In: Davies, R.J., Cartwright, J.A., Stewart, S.A., Lappin, M., Underhill, J.R. (Eds.), 3D Seismic Technology: Application to the Exploration of Sedimentary Basins. The Geological Society of London, Memoirs 29, pp. 53-61.

MacLachlan, S.E., Elliott, G.M., Parson, L.M., 2008. Investigations of the bottom current sculpted margin of Hatton Bank, NE Atlantic. Marine Geology 253, 170-184.

Marine Scotland, 2011a. A Strategy for Marine Nature Conservation in Scotland's Seas. The Scottish Government, Edinburgh. Available at:

$<$ http://www.scotland.gov.uk/Topics/marine/marineenvironment/Conservationstrategy/marineconstrategy> [Accessed on 25 July, 2016].

Marine Scotland, 2011b. Marine Protected Areas in Scotland's Seas. Guidelines on the Selection of MPAs and Development of the MPA Network. The Scottish Government, Edinburgh. Available at: <http://www.scotland.gov.uk/Topics/marine/marineenvironment/mpanetwork/mpaguidelines $>$ [Accessed on 25 July, 2016].

Marine Scotland, 2013. Nature Conservation Marine Protected Areas: Draft Management Handbook. The Scottish Government, Edinburgh. Available at:

$<$ http://www.scotland.gov.uk/Resource/0042/00428637.pdf $>$ [Accessed on 25 July, 2016].

Marine Scotland, 2016. Simple Guide to Fisheries Management Measure in Marine Protected Areas. The Scottish Government, Edinburgh. Available at: $<$ http://www.gov.scot/Resource/0049/00493862.pdf> [Accessed on 25 July, 2016].

Markus, T., Huhn, K., Bischof, K., 2015. The quest for sea-floor integrity. Nature Geoscience $8,163-164$.

Marren, P., 2002. Nature Conservation: a Review of the Conservation of Wildlife in Britain, 1950-2001. Harper Collins, London.

Masson, D.G., 2001. Sedimentary processes shaping the eastern slope of the Faeroe-Shetland Channel. Continental Shelf Research 21, 825-857.

Masson, D.G., Bett, B.J., Billett, D.S.M., Jacobs, C.L., Wheeler, A.J., Wynn, R.B., 2003. The origin of deep-water, coral-topped mounds in the northern Rockall Trough, Northeast Atlantic. Marine Geology 194, 159-180.

May, V.J., Hansom, J.D., 2003. Coastal Geomorphology of Great Britain. Geological Conservation Review Series No. 28. Joint Nature Conservation Committee, Peterborough.

McCave, I.N., 1971. Wave effectiveness at the sea bed and its relationship to bed-forms and the deposition of mud. Journal of Sedimentary Petrology 41, 89-96.

McIntyre, K.L., Howe, J.A., 2009. Bottom-current variability during the last glacial-deglacial transition, Northern Rockall Trough and Faroe Bank Channel, NE Atlantic. Scottish Journal of Geology 45, 43-58.

McIntyre, K.L., Howe, J.A., 2010. Scottish west coast fjords since the last glaciation: a review. In: Howe, J.A., Austin, W.E.N., Forwick, M., Paetzel, M. (Eds.), Fjord Systems and Archives. The Geological Society, London, Special Publications 344, pp. 305-329.

McIntyre, K., Howe, J., Bradwell, T., 2011. Lateglacial ice extent and deglaciation of Loch Hourn, western Scotland. Scottish Journal of Geology 47,169-178. 
Mienis, F., de Stigter, H.C., White, M., Duineveld, G., de Haas, H., van Weering T.C.E., 2007. Hydrodynamic controls on cold-water coral growth and carbonate-mound development at the SW and SE Rockall Trough Margin, NE Atlantic Ocean. Deep-Sea Research I 54, 1655-1674.

Merritt, J.W., Auton, C.A., Connell, E.R., Hall, A.M., Peacock, J.D., 2003. Cainozoic geology and landscape evolution of north-east Scotland. Memoir of the British Geological Survey. British Geological Survey, Edinburgh.

Millennium Ecosystem Assessment, 2005. Ecosystems and Human Well-being: Synthesis. Island Press, Washington DC.

Milne, G.A., Shennan, I., Youngs, B.A.R., Waugh, A.I., Teferle, F.N., Bingley, R.M., Bassett, S.E., Cuthbert-Brown, C., Bradley, S.L. 2006. Modelling the glacial isostatic adjustment of the UK region. Philosophical Transactions of the Royal Society A364, 931-948.

Mokeddem, Z., Baltzer, A., Goubert, E., Clet-Pellerin, M., 2010. A multiproxy palaeoenvironmental reconstruction of Loch Sunart (NW Scotland) since the Last Glacial Maximum. In: Howe, J.A., Austin, W.E.N., Forwick, M., Paetzel, M. (Eds.), Fjord Systems and Archives. Geological Society, London, Special Publications 344, pp. 341353.

Nielsen, T., De Santis, L., Dahlgren, K.I.T., Kuijpers, J.S., Laberg, J.S., Nygård, A., Praeg, D., Stoker, M.S., 2005. A comparison of the NW European glaciated margin with other glaciated margins. Marine and Petroleum Geology 22, 1149-1183.

Nørgaard-Pedersen, N., Austin, W.E.N., Howe, J.A., Shimmield, T., 2006. The Holocene record of Loch Etive, western Scotland: influence of catchment and relative sea level changes. Marine Geology 228, 55-71.

Ó Cofaigh, C., 2012. Ice sheets viewed from the ocean: the contribution of marine science to understanding modern and past ice sheets. Philosophical Transactions of the Royal Society A370, 5512-5539.

O'Connor, J.M., Stoffers, P., Wijbrans, J.R., Shannon, P.M., Morrisey, T., 2000. Evidence from episodic seamount volcanism for pulsing of the Iceland plume in the past $70 \mathrm{Myr}$. Nature 408, 954-958.

Peters, C., Walden, J., Austin, W.E.N., 2008. Magnetic signature of European margin sediments: provenance of ice-rafted debris and the climatic response of the British ice sheet during Marine Isotope Stages 2 and 3. Journal of Geophysical Research - Earth Surface 113, F03007, doi:10.1029/2007JF000836.

Praeg, D., Stoker, M.S., Shannon, P.M., Ceramicola, S., Hjelstuen, B., Laberg, J.S., Mathiesen, A., 2005. Episodic Cenozoic tectonism and the development of the NW European 'passive' continental margin. Marine and Petroleum Geology 22, 1007-1030.

Prosser, C.D., Brown, E.J., Larwood, J.G., Bridgland, D.R., 2013. Geoconservation for science and society - an agenda for the future. Proceedings of the Geologists' Association 124, 561-567.

Rasmussen, T.L., Backstrom, D., Heinemeier, J., Klitgard-Kristensen, D., Knutz, P., Kuipers, A., Lassen, S., Thomsen, E., Troelstra, S.R., van Weering, T.C.E., 2002. The FaroeShetland Gateway: Late Quaternary water mass exchange between the Nordic seas and the northeastern Atlantic. Marine Geology 188, 165-192. 
Rennie, A.F. 2006. The role of sediment supply and sea level changes on a submerging coast, past changes and future management implications. Unpublished $\mathrm{PhD}$ thesis, University of Glasgow.

Rice, J., Arvanitidis, C., Borja, A., Frid, C., Hiddink, J.G., Krause, J., Lorance, P., Ragnarsson, S.Á., Sköld, M., Trabucco, B., Enserink, L., Norkko, A., 2012. Indicators for sea-floor integrity under the European Marine Strategy Framework Directive. Ecological Indicators 12, 174-184.

Ritchie, J.D., Hitchen, K., 1996. Early Paleogene offshore igneous activity to the northwest of the UK and its relationship to the North Atlantic Igneous Province. In: Knox, R.W.O'B., Corfield, R.M., Dunay, R.E. (Eds.), Correlation of the Early Paleogene in Northwest Europe. The Geological Society, London, Special Publications 101, pp. 63-78.

Ritchie, J.D., Johnson, H., Quinn, M.F., Gatliff, R.W., 2008. The effects of Cenozoic compression within the Faroe - Shetland Basin and adjacent areas. In: Johnson, H., Dore, A.G., Gatliff, R.W., Holdsworth, R., Lundin, E.R., Ritchie, J.D. (Eds.), The Nature and Origin of Compression in Passive Margins. The Geological Society, London, Special Publications 306, pp. 121-136.

Ritchie, J.D., Ziska, H., Johnson, H., Evans, D. (Eds.), 2011. Geology of the Faeroe-Shetland Basin and Adjacent Areas. British Geological Survey, Nottingham, Research Report $\mathrm{RR} / 11 / 01$.

Roberts, J.M., Henry, L.A., Long, D., Hartley, J.P., 2008. Cold-water coral reef frameworks, megafaunal communities and evidence for coral carbonate mounds on the Hatton Bank, north east Atlantic. Facies 54, 297-316.

Roff, J.C., Taylor, M.E., Laughren, J., 2003. Geophysical approaches to the classification, delineation and monitoring of marine habitats and their communities. Aquatic Conservation: Marine and Freshwater Ecosystems 13, 77-90.

Rohling, E.J., Grant, K., Bolshaw, M., Roberts, A.P., Siddall, M., Hemleben, Ch., Kucera, M., 2009. Antarctic temperature and global sea level closely coupled over the past five glacial cycles. Nature Geoscience 2, 500-504.

Scoffin, T.P., 1988. The environments of production and deposition of calcareous sediments on the shelf west of Scotland. Sedimentary Geology 60, 107-124.

Scottish Government, 2013. 2020 Challenge for Scotland's Biodiversity. A Strategy for the Conservation and Enhancement of Biodiversity in Scotland. The Scottish Government, Edinburgh. Available at: <http://www.gov.scot/Resource/0042/00425276.pdf > [Accessed on 25 July, 2016].

Scottish Government, 2015. Scotland's National Marine Plan. A Single Framework for Managing Our Seas. The Scottish Government, Edinburgh. Available at: $<$ http://www.gov.scot/Resource/0047/00475466.pdf > [Accessed on 25 July, 2016].

Scottish Natural Heritage, 2014. Further advice to Scottish Government on the selection of Nature Conservation Marine Protected Areas for the development of the Scottish MPA network. Scottish Natural Heritage Commissioned Report No. 780. Available at: $<$ http://www.snh.org.uk/pdfs/publications/commissioned_reports/780.pdf $>$ [Accessed on 25 July, 2016]. 
Scottish Natural Heritage and the Joint Nature Conservation Committee, 2012. Advice to the Scottish Government on the selection of Nature Conservation Marine Protected Areas (MPAs) for the development of the Scottish MPA network. Scottish Natural Heritage Commissioned Report No. 547. Available at: $<$ http://www.snh.org.uk/pdfs/publications/commissioned_reports/547.pdf $>$ [Accessed on 25 July, 2016].

Scourse, J.D., Haapaniemi, A.I., Colmenero-Hidalgo, E., Peck, V.L., Hall, I.R., Austin, W.E.N., Knutz, P.C., Zahn, R., 2009. Growth, dynamics and deglaciation of the last British-Irish ice sheet: the deep-sea ice-rafted detritus record. Quaternary Science Reviews 28, 3066-3084.

Sejrup, H.P., Hjelstuen, B.O., Dahlgren, K.I.T., Haflidason, H., Kuijpers, A., Nygård, A., Praeg, D., Stoker, M.S., Vorren, T.O., 2005. Pleistocene glacial history of the NW European continental margin. Marine and Petroleum Geology 22, 1111-1129.

Sejrup, H.P., Nygård, A., Hall, A.M., Haflidason, H., 2009. Middle and Late Weichselian (Devensian) glaciation history of south-western Norway, North Sea and eastern UK. Quaternary Science Reviews 28, 370-380.

Small, D., Austin, W., Rinterknecht, V., 2013. Freshwater influx, hydrographic reorganisation and the dispersal of ice-rafted detritus in the sub-polar North Atlantic Ocean during the last glaciation. Journal of Quaternary Science 28, 527-535.

Small, D., Rinterknecht, V., Austin, W.E.N., Bates, R., Benn, D.I., Scourse, J.D., Bourlès, D.L., ASTER Team, Hibbert, F.D., 2016. Implications of ${ }^{36} \mathrm{Cl}$ exposure ages from Skye, northwest Scotland for the timing of ice stream deglaciation and deglacial ice dynamics. Quaternary Science Reviews 150, 130-145.

Smith, D.E., Shi, S., Cullingford, R.A., Dawson, A.G., Dawson, S., Firth, C.R., Foster, I.D.L., Fretwell, P.T., Haggart, B.A., Holloway, L.K., Long, D., 2004. The Holocene Storegga Slide tsunami in the United Kingdom. Quaternary Science Reviews 23, 22912321.

Smith, D.E., Harrison, S., Jordan, J.T., 2013. Sea level rise and submarine mass failures on open continental margins. Quaternary Science Reviews 82, 93-103.

Stewart, H., Davies, J., Long, D., Strömberg, H., Hitchen, K., 2009. JNCC Offshore Natura Survey: Anton Dohrn Seamount and East Rockall Bank. 2009/03-JNCC Cruise Report. Report No. CR/09/113. Joint Nature Conservation Committee, Peterborough. Available at: <http://jncc.defra.gov.uk/PDF/2009_3_JNCC_Cruise_Report_Public\%20(2).pdf> [Accessed on 25 July, 2016].

Stewart, M.A., Lonergan, L., 2011. Seven glacial cycles in the middle-late Pleistocene of northwest Europe: geomorphic evidence from buried tunnel valleys. Geology 39, 283286.

Stewart, M.A., Lonergan, L., Hampson, G., 2013. 3D seismic analysis of buried tunnel valleys in the central North Sea: morphology, cross-cutting generations and glacial history. Quaternary Science Reviews 72, 1-17.

Stoker, M.S., 1995. The influence of glacigenic sedimentation on slope-apron development on the continental margin off Northwest Britain. In: Scrutton, R.A., Stoker, M.S., Shimmield, G.B., Tudhope, A.W. (Eds.), The Tectonics, Sedimentation and Palaeoceanography of the North Atlantic Region. The Geological Society, London, Special Publications 90, pp. 159-177. 
Stoker, M., Bradwell, T., 2005. The Minch palaeo-ice stream, NW sector of the British-Irish ice sheet. Journal of the Geological Society of London 163, 425-428.

Stoker, M.S., Holmes, R., 1991. Submarine end-moraines as indicators of Pleistocene icelimits off northwest Britain. Journal of the Geological Society of London 148, 431-434.

Stoker, M.S., Hitchen, K., Graham, C.C., 1993. United Kingdom Offshore Report: the Geology of the Hebrides and West Shetland Shelves and Adjacent Deep-water Areas. HMSO for the British Geological Survey, London.

Stoker, M.S., Leslie, A.B., Scott, W.D., Briden, J.C., Hine, N.M., Harland, R., Wilkinson, I.P., Evans, D., Ardus, A.S., 1994. A record of late Cenozoic stratigraphy, sedimentation and climate change from the Hebrides Shelf, NE Atlantic Ocean. Journal of the Geological Society of London 151, 235-249.

Stoker, M.S., Praeg, D., Shannon, P.M., Hjelstuen, B.O., Laberg, J.S., Nielsen, T., van Weering, T.C.E., Sejrup, H.P., Evans, D., 2005. Neogene evolution of the Atlantic continental margin of NW Europe (Lofoten Islands to SW Ireland): anything but passive. In: Doré, A.G., Vining, B.A. (Eds.), Petroleum Geology: North-West Europe and Global Perspectives - Proceedings of the $6^{\text {th }}$ Petroleum Geology Conference. The Geological Society, London, pp. 1057-1076.

Stoker, M., Bradwell, T., Wilson, C., Harper, C., Smith, D., Brett, C., 2006. Pristine fjord landsystem revealed on the sea bed in the Summer Isles region, NW Scotland. Scottish Journal of Geology 42, 89-99.

Stoker, M.S., Bradwell, T., Howe, J.A., Wilkinson, I.P., McIntyre, K., 2009. Lateglacial icecap dynamics in NW Scotland: evidence from the fjords of the Summer Isles region. Quaternary Science Reviews 28, 3161-3184.

Stoker, M., Holford, S.P., Hillis, R., Green, P.F., Duddy, I.R., 2010a. Cenozoic post-rift sedimentation off northwest Britain: recording the detritus of episodic uplift on a passive continental margin. Geology 38, 595-598.

Stoker, M.S., Wilson, C.R., Howe, J.A., Bradwell, T., Long, D., 2010b. Paraglacial slope instability in Scottish fjords: examples from Little Loch Broom, NW Scotland. In: Howe, J.A., Austin, W.E.N., Forwick, M., Paetzel, M. (Eds.), Fjord Systems and Archives. The Geological Society, London, Special Publications 344, pp. 225-242.

Sutherland, D.G., 1984a. The Quaternary deposits and landforms of Scotland and the neighbouring shelves: a review. Quaternary Science Reviews 3, 157-254.

Sutherland, D.G., 1984b. The submerged landforms of the St. Kilda archipelago, western Scotland. Marine Geology 58, 435-442.

Sutherland, D.G., 1987. Submerged rock platforms on the continental shelf west of Sula Sgeir. Scottish Journal of Geology 23, 251-260.

Theobald, D.M., Harrison-Atlas, D., Monahan, W.B., Albano, C.M., 2015. Ecologicallyrelevant maps of landforms and physiographic diversity for climate adaptation planning. PLoS ONE 10(12): e0143619.doi:10.1371/journal.pone.0143619.

Thierens, M., Pirlet, H., Colin, C., Latruwe, K., Vanhaecke, F., Lee, J.R., Stuut, J.B., Titschack, J., Huvenne, V.A.I., Dorschel, B., Wheeler, A.J., Henriet, J.P., 2012. Icerafting from the British-Irish ice sheet since the earliest Pleistocene (2.6 million years ago): implications for long-term mid-latitudinal ice-sheet growth in the North Atlantic region. Quaternary Science Reviews 44, 229-240. 
Thorsnes, T., Erikstad, L., Dolan, M.F.J., Bellec, V., 2009. Submarine landscapes along the Lofoten-Vesterålen-Senja margin, northern Norway. Norwegian Journal of Geology 89, 5-16.

Todd, B.J., Greene, H.G., 2007.Mapping the seafloor for habitat characterization. Geological Association of Canada, Special Publication 47.

UK National Ecosystem Assessment, 2011. The UK National Ecosystem Assessment: Synthesis of the Key Findings. UNEP-WCMC, Cambridge.

van der Vegt, P., Janszen, A., Moscariello, A., 2012. Tunnel valleys: current knowledge and future perspectives. In: Huuse, M., Redfern, J., Le Heron, D.P., Dixon, R.J.,

Moscariello, A., Craig, J. (Eds.), Glaciogenic Reservoirs and Hydrocarbon Systems. The Geological Society, London, Special Publications 368, pp. 75-97.

Vaughan, D.G., Arthern, R., 2007. Why is it hard to predict the future of ice sheets? Science $135,1503-1504$.

Von Weymarn, J., 1974. Coastline development in Lewis and Harris, Outer Hebrides, with particular reference to the effects of glaciation. Unpublished $\mathrm{PhD}$ thesis, University of Aberdeen.

Wilson, L.J., Austin, W.E.N., 2002. Millenial and sub-millenial-scale variability in sediment colour from the Barra Fan, NW Scotland: implications for British ice sheet dynamics. In: Dowdeswell, J.A., O Cofaigh, C. (Eds.), Glacier-Influenced Sedimentation on HighLatitude Continental Margins. The Geological Society, London, Special Publications 203, pp. 349-365.

Wilson, L.J., Austin, W.E.N., Jansen, E., 2002. The last British Ice Sheet: growth, maximum extent and deglaciation. Polar Research 21, 243-250. 


\section{Table 1}

Stage 1 guidelines for the identification of search locations containing MPA search features with particular reference to geodiversity interests (from Marine Scotland, 2011b).

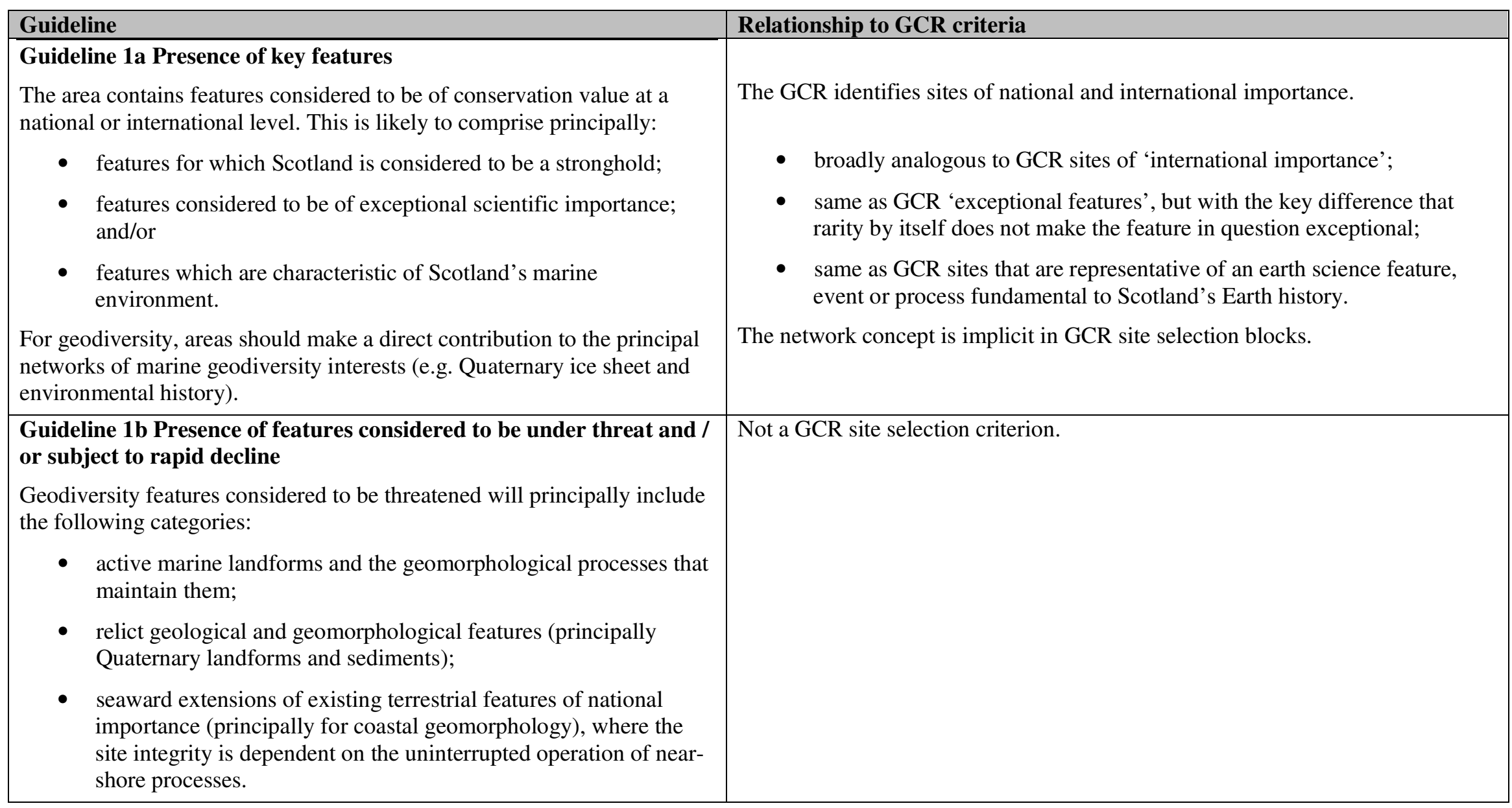




\section{Guideline}

Guideline 1c Functional significance for the overall health and

diversity of Scottish Seas

The area does not necessarily contain key and/or threatened/declining features, but provides ecological resources or geomorphological processes considered to be critical to the functioning of wider marine ecosystems, e.g. places for feeding, breeding, resting, nurseries, juveniles and/or spawning, or sediment supply.
Relationship to GCR criteria

Not a GCR site selection criterion. 


\section{Table 2}

Search features (thematic blocks) representing the key geodiversity interests of the Scottish seabed and their scientific importance.

\begin{tabular}{|c|c|c|}
\hline & Features / thematic blocks & Interests of scientific importance \\
\hline 1 & The Quaternary of Scotland & $\begin{array}{l}\text { A range of landforms and deposits associated with the last and earlier British-Irish Ice Sheet(s), important } \\
\text { for: } \\
\text { - recording the history of ice sheet glaciation during the Quaternary; } \\
\text { - understanding the dynamics of palaeo-ice streams and marine-based ice sheets and the links to climate } \\
\text { forcing and sea level; } \\
\text { - insights into the coupling of ice-sheet dynamics, ocean processes, climate, the rheology of the upper } \\
\text { mantle, glacio-isostatic adjustment and relative sea-level changes; } \\
\text { - geomorphological and sedimentary records that augment the terrestrial evidence for the later stages of } \\
\text { deglaciation of the last British-Irish Ice Sheet and the subsequent re-expansion of glaciers in the north } \\
\text { and west Highlands during the Loch Lomond (Younger Dryas) Stade; } \\
\text { - the length and continuity of palaeoenvironmental archives that elucidate regional-scale changes in } \\
\text { palaeoceanography and climate variations, fluctuations in the timing and extent of the last British-Irish } \\
\text { Ice Sheet and changing sedimentation patterns and processes. }\end{array}$ \\
\hline 2 & Submarine Mass Movement & $\begin{array}{l}\text { Submarine slides of different ages and morphology, important for understanding: } \\
\text { - the geological evolution and processes that have shaped the continental slope; } \\
\text { - geohazards associated with the thick sediment accumulations on the continental slope. }\end{array}$ \\
\hline 3 & $\begin{array}{l}\text { Marine Geomorphology of } \\
\text { the Scottish Deep-Ocean } \\
\text { Seabed }\end{array}$ & $\begin{array}{l}\text { Contourites, sediment drifts and erosional features associated with deep-ocean currents, important for } \\
\text { understanding: } \\
\text { - past and present processes associated with ocean currents; } \\
\text { - links between sedimentation patterns, palaeoceanographic changes and past climate changes. }\end{array}$ \\
\hline 4 & Seabed Fluid and Gas Seep & $\begin{array}{l}\text { Pockmarks and sand volcanoes, important for understanding: } \\
\text { - } \quad \text { syn-/post- depositional processes associated with thick sediment accumulations on the seafloor; } \\
\text { - } \quad \text { bedforms associated with gas seepage from the seafloor. }\end{array}$ \\
\hline
\end{tabular}




\begin{tabular}{|l|l|l|}
\hline & Features / thematic blocks & Interests of scientific importance \\
\hline 5 & $\begin{array}{l}\text { Cenozoic Structures of the } \\
\text { Atlantic Margin }\end{array}$ & $\begin{array}{l}\text { Large structural blocks (seamounts) and mud diapirs, important for understanding: } \\
\text { - the history and dynamic evolution of a 'passive' continental margin, including part of the North Atlantic } \\
\text { Volcanic Province; } \\
\text { - sub-surface fluid migration pathways. }\end{array}$ \\
\hline 6 & $\begin{array}{l}\text { Marine Geomorphology of } \\
\text { the Scottish Shelf Seabed }\end{array}$ & $\begin{array}{l}\text { Internationally important examples of non-tropical shelf carbonate systems and bedforms, including horse- } \\
\text { mussel reefs and banks of coralline algal gravels (maerl), important for: } \\
\text { - sources of sediment for machair systems; } \\
\text { - understanding shelf processes and relationships between currents and bedform development. }\end{array}$ \\
\hline 7 & $\begin{array}{l}\text { Coastal Geomorphology of } \\
\text { Scotland }\end{array}$ & $\begin{array}{l}\text { Submerged coastal landforms, important for: } \\
\text { - recording past changes in relative sea level; } \\
\text { - understanding processes of shore platform formation. }\end{array}$ \\
\hline 8 & $\begin{array}{l}\text { Biogenic Structures of the } \\
\text { Scottish Seabed }\end{array}$ & $\begin{array}{l}\text { Biogenic sediment mounds and cold-water corals, important for understanding: } \\
\text { - the formation and evolution of cold-water coral growth and carbonate mound development. }\end{array}$ \\
\hline
\end{tabular}




\section{Table 3}

Summary of ecosystem services provided by Scotland's marine geodiversity.

\begin{tabular}{|c|c|}
\hline Ecosystem service $^{1}$ & Service detail \\
\hline \multicolumn{2}{|l|}{ Regulating } \\
\hline Ocean circulation & Submarine topography regulates ocean circulation and dynamic processes \\
\hline $\begin{array}{l}\text { Natural hazard } \\
\text { regulation }\end{array}$ & $\begin{array}{l}\text { The presence of beaches and saltmarshes at the coast provides natural } \\
\text { forms of coast defence, helping to attenuate wave energy close to shore } \\
\text { and reduce damage caused by waves and storms. }\end{array}$ \\
\hline $\begin{array}{l}\text { limate change and } \\
\text { greenhouse gas } \\
\text { regulation }\end{array}$ & Marine sediments are stores of blue carbon. \\
\hline \multicolumn{2}{|l|}{ Supporting } \\
\hline Habitat provision & $\begin{array}{l}\text { Submarine landforms, geomorphological processes and substrate } \\
\text { properties support a diverse range of marine habitats and species. }\end{array}$ \\
\hline $\begin{array}{l}\text { Natural harbours and } \\
\text { seaways }\end{array}$ & $\begin{array}{l}\text { Geological and geomorphological features provide seaways (straits), } \\
\text { natural harbours and sheltered inlets. }\end{array}$ \\
\hline \multicolumn{2}{|l|}{ Provisioning } \\
\hline Food & $\begin{array}{l}\text { Marine geodiversity provides habitats for economic species. Many key } \\
\text { fishing grounds are associated with geodiversity features (e.g. Wee } \\
\text { Bankie, Rockall and the Southern Trench). }\end{array}$ \\
\hline Fuel & $\begin{array}{l}\text { Marine geology supplies essential non-renewable energy resources (oil, } \\
\text { gas and coal). }\end{array}$ \\
\hline Minerals & $\begin{array}{l}\text { Marine geology and geomorphology supply essential non-renewable, non- } \\
\text { energy minerals (e.g. construction aggregates). }\end{array}$ \\
\hline Renewable energy & $\begin{array}{l}\text { Marine geology, topography and natural processes help to provide } \\
\text { renewable forms of energy (tidal power, wind power, geothermal power), } \\
\text { as well as platforms for their development. }\end{array}$ \\
\hline Cultural & \\
\hline
\end{tabular}




\begin{tabular}{|l|l|}
\hline Ecosystem service $^{\mathbf{1}}$ & Service detail \\
\hline $\begin{array}{l}\text { Knowledge } \\
\text { systems/capital }\end{array}$ & $\begin{array}{l}\text { Knowledge of marine geology and geomorphology contributes to } \\
\text { understanding of Earth history, materials, resources and hazards. Records } \\
\text { of past climate and environmental changes preserved in seafloor landform } \\
\text { and sedimentary archives are crucial to understanding past climate change } \\
\text { and informing future scenarios. The landforms and deposits on the } \\
\text { Scottish shelf are particularly relevant for understanding the dynamics of } \\
\text { contemporary marine-based ice sheets and their responses to global } \\
\text { warming. Knowledge of physical processes, materials and their history } \\
\text { also underpins understanding of marine ecosystems and provides a long- } \\
\text { term perspective on ecosystem status, trends, rates of change and future } \\
\text { trajectories. }\end{array}$ \\
\hline Educational values & $\begin{array}{l}\text { Marine geology and geomorphology have value for both formal and } \\
\text { informal education about the Earth for people of all ages and across a } \\
\text { wide range of disciplines. }\end{array}$ \\
\hline Cultural heritage values & $\begin{array}{l}\text { Many marine and coastal features have significant geoheritage value. } \\
\text { They also have a profound influence on coastal and seascape character, } \\
\text { and have influenced past and present patterns of human habitation and } \\
\text { way of life at the coast. }\end{array}$ \\
\hline Artistic inspiration & $\begin{array}{l}\text { The highly varied physical character of coastal landscapes and seascapes } \\
\text { is a strong influence on art, literature, poetry and music. }\end{array}$ \\
\hline $\begin{array}{l}\text { Recreation and } \\
\text { ecotourism }\end{array}$ & $\begin{array}{l}\text { Geodiversity provides a great variety of coastal scenery and beaches for } \\
\text { recreation and geotourism, as well as opportunities for recreational diving } \\
\text { and the range of habitats and species of interest. }\end{array}$ \\
\hline
\end{tabular}

${ }^{1}$ From Millennium Ecosystem Assessment (2005). 


\section{Table 4}

List of geodiversity key areas in Scottish waters categorised by thematic block.

\begin{tabular}{|c|c|c|}
\hline Thematic block & Geodiversity key area name & Ref. no \\
\hline \multirow[t]{11}{*}{ The Quaternary of Scotland } & Summer Isles to Sula Sgeir Fan & $1 \mathrm{a} \& \mathrm{~b}$ \\
\hline & The Small Isles & 2 \\
\hline & Loch Linnhe and Loch Etive & 3 \\
\hline & West Shetland Margin Palaeo-depositional System & 4 \\
\hline & The Southern Trench & 5 \\
\hline & Devil's Hole & 6 \\
\hline & Fladen Deeps & 7 \\
\hline & Wee Bankie & 8 \\
\hline & Bosies Bank & 9 \\
\hline & North Sea Fan (Scottish sector) & 10 \\
\hline & The Barra Fan & 11 \\
\hline \multirow[t]{4}{*}{ Submarine Mass Movement } & Geikie Slide & 12 \\
\hline & The Afen Slide and Palaeo-Afen Slide & 13 \\
\hline & The Peach Slide Complex & 14 \\
\hline & Miller Slide & 15 \\
\hline \multirow{5}{*}{$\begin{array}{l}\text { Marine Geomorphology of } \\
\text { the Scottish Deep-Ocean } \\
\text { Seabed }\end{array}$} & West Shetland Margin Contourite Deposits & $16 \mathrm{a}-\mathrm{c}$ \\
\hline & Central Hatton Bank (and adjacent basin floor) & 17 \\
\hline & Rosemary Bank Seamount (and adjacent basin floor) & 18 \\
\hline & North-East Rockall Bank (and adjacent basin floor) & 19 \\
\hline & George Bligh Bank (and adjacent basin floor) & 20 \\
\hline \multirow[t]{2}{*}{ Seabed Fluid and Gas Seep } & Darwin Mounds & 21 \\
\hline & Scanner - Scotia - Challenger Pockmark Complex & $22 \mathrm{a} \& \mathrm{~b}$ \\
\hline \multirow{2}{*}{$\begin{array}{l}\text { Cenozoic Structures of the } \\
\text { Atlantic Margin }\end{array}$} & Anton Dohrn Seamount (and adjacent basin floor) & 23 \\
\hline & The Pilot Whale Diapirs & 24 \\
\hline
\end{tabular}




\begin{tabular}{|l|l|c|}
\hline Thematic block & Geodiversity key area name & Ref. no \\
\hline \multirow{4}{*}{$\begin{array}{l}\text { Marine Geomorphology of } \\
\text { the Scottish Shelf Seabed }\end{array}$} & Sandy Riddle Bank & 25 \\
\cline { 2 - 3 } & Fair Isles Strait Marine Process Bedforms & 26 \\
\cline { 2 - 3 } & Outer Hebrides Carbonate Production Area & 27 \\
\cline { 2 - 3 } & Inner Hebrides Carbonate Production Area & 28 \\
\cline { 2 - 3 } & Orkney Carbonate Production Area & 29 \\
\cline { 2 - 3 } & Shetland Carbonate Production Area & 30 \\
\hline \multirow{4}{*}{$\begin{array}{l}\text { Soastal Geomorphology of } \\
\text { Scotland }\end{array}$} & St Kilda Archipelago Submerged Landforms & 31 \\
\cline { 2 - 3 } $\begin{array}{l}\text { Biogenic Structures of the } \\
\text { Scottish Seabed }\end{array}$ & Sula Sgeir Submerged Platforms & 32 \\
\cline { 2 - 3 } & Rockall Bank Biogenic Sediment Mounds & 33 \\
\cline { 2 - 3 } & Hatton Bank Carbonate Mounds & 34 \\
\cline { 2 - 3 } & Mingulay Reef & 35 \\
\hline
\end{tabular}




\section{Table 5}

Generic assessment of the potential sensitivity of the principal component interests of the geodiversity features; see text for list of pressures (adapted from Brooks, 2013).

\begin{tabular}{|c|c|c|}
\hline Feature & Component interest & Potential sensitivity to principal pressures \\
\hline \multirow{7}{*}{$\begin{array}{l}\text { Quaternary of } \\
\text { Scotland }\end{array}$} & Continental slope channels & $\begin{array}{l}\text { Medium to physical extraction (potential to cause partial disruption to the surface or } \\
\text { stratigraphy). }\end{array}$ \\
\hline & Glaciated channel/trough (bedrock) & Low to all. \\
\hline & Iceberg ploughmark field & High to physical extraction; Medium to sub-surface scour. \\
\hline & $\begin{array}{l}\text { Landscape of areal glacial scour } \\
\text { (bedrock) }\end{array}$ & Low to all. \\
\hline & Mega-scale glacial lineations & High to physical extraction; Medium to sub-surface scour and water-flow changes. \\
\hline & Prograding wedge & Low. \\
\hline & Sub-glacial tunnel valley & Low. \\
\hline \multirow{3}{*}{$\begin{array}{l}\text { Submarine Mass } \\
\text { Movement }\end{array}$} & Continental slope turbidite canyons & $\begin{array}{l}\text { Medium to physical extraction (potential to cause partial disruption to the surface or } \\
\text { stratigraphy). }\end{array}$ \\
\hline & Slide deposit & High to physical extraction; Medium to sub-surface scour; Medium to water-flow changes. \\
\hline & Slide scars & Low to all. \\
\hline \multirow{5}{*}{$\begin{array}{l}\text { Marine } \\
\text { Geomorphology of } \\
\text { the Scottish Deep- } \\
\text { Ocean Seabed }\end{array}$} & Contourite sand/silt & High to physical extraction. \\
\hline & Sand wave field & Medium to physical extraction (dynamic feature with potential to recover). \\
\hline & Sediment drift & Low to all. \\
\hline & Sediment wave field & Medium to sub-surface scour. \\
\hline & Polygonal faults & Low to all. \\
\hline $\begin{array}{l}\text { Seabed Fluid and } \\
\text { Gas Seep }\end{array}$ & Pockmarks & Medium to water-flow (tidal current) changes. \\
\hline \multirow{4}{*}{$\begin{array}{l}\text { Cenozoic } \\
\text { Structures of the } \\
\text { Atlantic Margin }\end{array}$} & Continental slope & Low to all. \\
\hline & Hebrides Terrace Seamount & Low to all. \\
\hline & Mud diapirs & Low to all. \\
\hline & Rosemary Bank Seamount & Low to all. \\
\hline
\end{tabular}




\begin{tabular}{|c|c|c|}
\hline Feature & Component interest & Potential sensitivity to principal pressures \\
\hline \multirow{6}{*}{$\begin{array}{l}\text { Marine } \\
\text { Geomorphology of } \\
\text { the Scottish Shelf } \\
\text { Seabed }\end{array}$} & Bank (unknown substrate) & High to water-flow (tidal current) changes. \\
\hline & Longitudinal bedform field & High to water-flow (tidal current) changes; High to physical extraction. \\
\hline & Sand bank & High to water-flow (tidal current) changes; High to physical extraction. \\
\hline & Sand ribbon field & High to water-flow (tidal current) changes; High to physical extraction. \\
\hline & Sand wave field & High to water-flow (tidal current) changes; High to physical extraction. \\
\hline & Sediment wave field & High to water-flow (tidal current) changes; High to physical extraction. \\
\hline \multirow{3}{*}{$\begin{array}{l}\text { Coastal } \\
\text { Geomorphology of } \\
\text { Scotland }\end{array}$} & Carbonate sand deposits & High to water-flow (tidal current) changes; High to physical extraction. \\
\hline & Submerged platforms, cliffs and caves & Low to all. \\
\hline & Submerged peat & $\begin{array}{l}\text { High to physical extraction, seabed surface scour/penetration, sub-seabed surface } \\
\text { scour/penetration, water-flow (tidal current) changes, wave-exposure changes and siltation- } \\
\text { rate changes. }\end{array}$ \\
\hline $\begin{array}{l}\text { Biogenic Structures } \\
\text { of the Scottish } \\
\text { Seabed }\end{array}$ & Carbonate mounds and reefs & $\begin{array}{l}\text { High to physical extraction, seabed surface scour/penetration, sub-seabed surface } \\
\text { scour/penetration, water-flow (tidal current) changes, wave-exposure changes and siltation- } \\
\text { rate changes. }\end{array}$ \\
\hline
\end{tabular}




\section{Table 6}

Summary of overlaps of geodiversity key areas with MPAs, MPA p and other area-based measures.

\begin{tabular}{|c|c|c|c|c|}
\hline No. & Geodiversity Key Areas & $\begin{array}{l}\text { Proportion of geodiversity key } \\
\text { areas within Nature } \\
\text { Conservation MPAs/MPA } \\
\text { proposals } \\
(100 \%,>75 \%, 75-25 \%,<25 \% \text {, } \\
0 \%)\end{array}$ & $\begin{array}{l}\text { Proportion of geodiversity key areas within other protected } \\
\text { areas covered by existing measures (SACs, SPAs, Fisheries } \\
\text { Areas) } \\
(100 \%,>75 \%, 75-25 \%,<25 \%, 0 \%)\end{array}$ & $\begin{array}{l}\text { Geodiversity } \\
\text { interest } \\
\text { recognised as a } \\
\text { protected feature } \\
\text { of MPAs/MPA } \\
\text { proposals }\end{array}$ \\
\hline \multicolumn{5}{|c|}{ Quaternary of Scotland } \\
\hline $1 \mathrm{a}$ & Summer Isles & $\begin{array}{l}<25 \% \\
\text { (Wester Ross, Shiant East Bank } \\
\text { and North-east Lewis MPA } \\
\text { proposals) }\end{array}$ & $\begin{array}{l}<25 \% \\
\text { (Priest Island SPA) }\end{array}$ & Yes \\
\hline $1 \mathrm{~b}$ & Sula Sgeir Fan & $\begin{array}{l}<25 \%^{1} \\
\text { (West Shetland Shelf) }\end{array}$ & $\begin{array}{l}<25 \% \\
\text { (Edge of Scottish continental shelf blue ling protection area } \\
\text { Fisheries Area) }\end{array}$ & No \\
\hline 2 & The Small Isles & $\begin{array}{l}<25 \% \\
\text { (Small Isles, Loch Sunart, Loch } \\
\text { Sunart to the Sound of Jura) } \\
>75 \% \\
\text { (Sea of Hebrides MPA proposal) }^{2} \\
\end{array}$ & $\begin{array}{l}<25 \% \\
\text { (Canna and Sanday SPA, Rum SPA, Lochs Duich, Long and } \\
\text { Alsh SAC, Sound of Arisaig SAC, Sunart SAC) }\end{array}$ & In part \\
\hline 3 & $\begin{array}{l}\text { Loch Linnhe and Loch } \\
\text { Etive }\end{array}$ & $\begin{array}{l}25-75 \% \\
\text { (Loch Sunart to the Sound of Jura, } \\
\text { Loch Creran) }\end{array}$ & \begin{tabular}{|l|}
$<25 \%$ \\
(Eileanan agus Sgeiran Lios mór SAC, Loch Creran SAC, \\
Firth of Lorn SAC) \\
\end{tabular} & Yes \\
\hline 4 & $\begin{array}{l}\text { West Shetland Margin } \\
\text { Palaeo-depositional } \\
\text { System }\end{array}$ & $\begin{array}{l}<25 \% \\
\text { (Faroe-Shetland Sponge Belt) }\end{array}$ & $0 \%$ & Yes \\
\hline
\end{tabular}




\begin{tabular}{|c|c|c|c|c|}
\hline No. & Geodiversity Key Areas & $\begin{array}{l}\text { Proportion of geodiversity key } \\
\text { areas within Nature } \\
\text { Conservation MPAs/MPA } \\
\text { proposals } \\
(100 \%,>75 \%, 75-25 \%,<25 \% \text {, } \\
0 \%)\end{array}$ & $\begin{array}{l}\text { Proportion of geodiversity key areas within other protected } \\
\text { areas covered by existing measures (SACs, SPAs, Fisheries } \\
\text { Areas) } \\
(100 \%,>75 \%, 75-25 \%,<25 \%, 0 \%)\end{array}$ & $\begin{array}{l}\text { Geodiversity } \\
\text { interest } \\
\text { recognised as a } \\
\text { protected feature } \\
\text { of MPAs/MPA } \\
\text { proposals }\end{array}$ \\
\hline 5 & The Southern Trench & $\begin{array}{l}100 \% \\
\text { (The Southern Trench MPA } \\
\text { proposal) }\end{array}$ & $\begin{array}{l}25 \%-75 \% \\
\text { (East Coast of Scotland sandeel closure Fisheries Area) }\end{array}$ & Yes \\
\hline 6 & Devil's Hole & $0 \%$ & $0 \%$ & - \\
\hline 7 & Fladen Deeps & $\begin{array}{l}<25 \% \\
\text { (Central Fladen) }\end{array}$ & $0 \%$ & Yes \\
\hline 8 & Wee Bankie & $\begin{array}{l}25-75 \% \\
\text { (Firth of Forth Banks Complex) }\end{array}$ & $\begin{array}{l}100 \% \\
\text { (East Coast of Scotland sandeel closure Fisheries Area) }\end{array}$ & Yes \\
\hline 9 & Bosies Bank & $0 \%$ & $\begin{array}{l}25 \%-75 \% \\
\text { (East Coast of Scotland sandeel closure Fisheries Area) }\end{array}$ & - \\
\hline 10 & $\begin{array}{l}\text { North Sea Fan (Scottish } \\
\text { sector) }\end{array}$ & $\begin{array}{l}>75 \%^{3} \\
\text { (North-east Faroe-Shetland } \\
\text { Channel })^{4} \text {. }\end{array}$ & 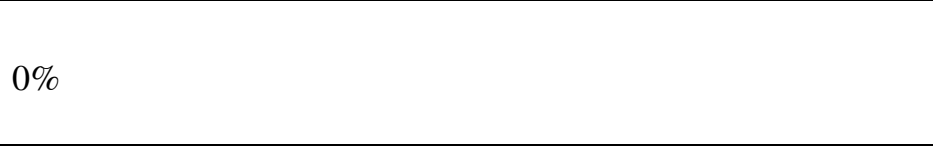 & No \\
\hline 11 & The Barra Fan & $\begin{array}{l}25-75 \% \\
\text { (The Barra Fan and Hebrides } \\
\text { Terrace Seamount) }\end{array}$ & $0 \%$ & Yes \\
\hline \multicolumn{5}{|c|}{ Submarine Mass Movement } \\
\hline 12 & Geikie Slide & $\begin{array}{l}100 \% \\
\text { (Geikie Slide and Hebridean } \\
\text { Slope) }\end{array}$ & $0 \%$ & Yes \\
\hline 13 & $\begin{array}{l}\text { The Afen Slide and } \\
\text { Palaeo-Afen Slide }\end{array}$ & $0 \%$ & $0 \%$ & - \\
\hline
\end{tabular}




\begin{tabular}{|c|c|c|c|c|}
\hline No. & Geodiversity Key Areas & $\begin{array}{l}\text { Proportion of geodiversity key } \\
\text { areas within Nature } \\
\text { Conservation MPAs/MPA } \\
\text { proposals } \\
(100 \%,>75 \%, 75-25 \%,<25 \% \text {, } \\
0 \%)\end{array}$ & $\begin{array}{l}\text { Proportion of geodiversity key areas within other protected } \\
\text { areas covered by existing measures (SACs, SPAs, Fisheries } \\
\text { Areas) } \\
(100 \%,>75 \%, 75-25 \%,<25 \%, 0 \%)\end{array}$ & $\begin{array}{l}\text { Geodiversity } \\
\text { interest } \\
\text { recognised as a } \\
\text { protected feature } \\
\text { of MPAs/MPA } \\
\text { proposals }\end{array}$ \\
\hline 14 & The Peach Slide Complex & $\begin{array}{l}<25 \% \\
\text { (The Barra Fan and Hebrides } \\
\text { Terrace Seamount) }\end{array}$ & $0 \%$ & Yes \\
\hline 15 & Miller Slide & $\begin{array}{l}100 \% \\
\text { (North-east Faroe-Shetland } \\
\text { Channel) }\end{array}$ & $0 \%$ & Yes \\
\hline \multicolumn{5}{|c|}{ Marine Geomorphology of the Scottish Deep-Ocean Seabed } \\
\hline $16 \mathrm{a}$ & $\begin{array}{l}\text { West Shetland Margin } \\
\text { Contourite Deposits }\end{array}$ & $\begin{array}{l}>75 \% \\
\text { (Faroe-Shetland Sponge Belt, } \\
\text { North-east Faroe-Shetland } \\
\text { Channel) }\end{array}$ & $0 \%$ & Yes \\
\hline $\begin{array}{l}16 b \\
-c\end{array}$ & $\begin{array}{l}\text { West Shetland Margin } \\
\text { Contourite Deposits }\end{array}$ & $0 \%$ & $0 \%$ & - \\
\hline 17 & $\begin{array}{l}\text { Central Hatton Bank (and } \\
\text { adjacent basin floor) }\end{array}$ & $\begin{array}{l}<25 \%^{1} \\
\text { (Hatton-Rockall Basin) tiny } \\
\text { overlap but included as a } \\
\text { protected feature }\end{array}$ & $\begin{array}{l}25-75 \% \\
\text { (Hatton Bank cSAC and Fisheries Area) }\end{array}$ & Yes \\
\hline 18 & $\begin{array}{l}\text { Rosemary Bank Seamount } \\
\text { (and adjacent basin floor) }\end{array}$ & $\begin{array}{l}100 \% \\
\text { (Rosemary Bank Seamount) }\end{array}$ & $\begin{array}{l}>75 \% \\
\text { (Edge of Rosemary Bank blue ling protection Fisheries Area) }\end{array}$ & Yes \\
\hline 19 & $\begin{array}{l}\text { North-East Rockall Bank } \\
\text { (and adjacent basin floor) }\end{array}$ & $0 \%$ & $\begin{array}{l}25-75 \% \\
\text { (NW Rockall Bank SAC, East Rockall Bank cSAC, North } \\
\text { West Rockall Fisheries Area) }\end{array}$ & - \\
\hline 20 & $\begin{array}{l}\text { George Bligh Bank (and } \\
\text { adjacent basin floor) }\end{array}$ & $0 \%$ & $0 \%$ & - \\
\hline
\end{tabular}




\begin{tabular}{|c|c|c|c|c|}
\hline No. & Geodiversity Key Areas & $\begin{array}{l}\text { Proportion of geodiversity key } \\
\text { areas within Nature } \\
\text { Conservation MPAs/MPA } \\
\text { proposals } \\
(100 \%,>75 \%, 75-25 \%,<25 \% \text {, } \\
0 \%)\end{array}$ & $\begin{array}{l}\text { Proportion of geodiversity key areas within other protected } \\
\text { areas covered by existing measures (SACs, SPAs, Fisheries } \\
\text { Areas) } \\
(100 \%,>75 \%, 75-25 \%,<25 \%, 0 \%)\end{array}$ & $\begin{array}{l}\text { Geodiversity } \\
\text { interest } \\
\text { recognised as a } \\
\text { protected feature } \\
\text { of MPAs/MPA } \\
\text { proposals }\end{array}$ \\
\hline \multicolumn{5}{|c|}{ Seabed Fluid and Gas Seep } \\
\hline 21 & Darwin Mounds & $0 \%$ & $\begin{array}{l}100 \% \\
\text { (Darwin Mounds SAC and Fisheries Area) }\end{array}$ & - \\
\hline $\begin{array}{c}22 \mathrm{a} \\
\& \\
\mathrm{~b}\end{array}$ & $\begin{array}{l}\text { Scanner - Scotia - } \\
\text { Challenger Pockmark } \\
\text { Complex }\end{array}$ & $0 \%$ & $\begin{array}{l}25-75 \% \\
\text { (Scanner Pockmark SAC) }\end{array}$ & - \\
\hline \multicolumn{5}{|c|}{ Cenozoic Structures of the Atlantic Margin } \\
\hline 23 & $\begin{array}{l}\text { Anton Dohrn Seamount } \\
\text { (and adjacent basin floor) }\end{array}$ & $0 \%$ & $\begin{array}{l}>75 \% \\
\text { (Anton Dohrn Seamount cSAC) }\end{array}$ & - \\
\hline \multicolumn{5}{|c|}{ Marine Geomorphology of the Scottish Shelf Seabed } \\
\hline 25 & Sandy Riddle Bank & $0 \%$ & $0 \%$ & - \\
\hline 26 & $\begin{array}{l}\text { Fair Isle Strait Marine } \\
\text { Process Bedforms }\end{array}$ & $\begin{array}{l}<25 \% \\
\text { (North-west Orkney, Papa } \\
\text { Westray, Wyre and Rousay } \\
\text { Sounds) } \\
\end{array}$ & $\begin{array}{l}<25 \% \\
\text { (Foula SPA, Fair Isle SPA, East Coast of Sanday SAC, Calf of } \\
\text { Eday SPA, Faray and Holm of Faray SAC, Rousay SPA, West } \\
\text { Westray SPA) }\end{array}$ & Yes \\
\hline 27 & $\begin{array}{l}\text { Outer Hebrides Carbonate } \\
\text { Production Area }\end{array}$ & $\begin{array}{l}<25 \% \\
\text { (Monach Islands) }\end{array}$ & $\begin{array}{l}<25 \% \\
\text { (Loch Roag Lagoons SAC, } \\
\text { North Uist Machair and Islands SPA, Monach Islands SAC, } \\
\text { South Uist Machair SAC, Mingulay and Berneray SPA) }\end{array}$ & Yes \\
\hline
\end{tabular}




\begin{tabular}{|c|c|c|c|c|}
\hline No. & Geodiversity Key Areas & $\begin{array}{l}\text { Proportion of geodiversity key } \\
\text { areas within Nature } \\
\text { Conservation MPAs/MPA } \\
\text { proposals } \\
(100 \%,>75 \%, 75-25 \%,<25 \% \text {, } \\
0 \%)\end{array}$ & $\begin{array}{l}\text { Proportion of geodiversity key areas within other protected } \\
\text { areas covered by existing measures (SACs, SPAs, Fisheries } \\
\text { Areas) } \\
(100 \%,>75 \%, 75-25 \%,<25 \%, 0 \%)\end{array}$ & $\begin{array}{l}\text { Geodiversity } \\
\text { interest } \\
\text { recognised as a } \\
\text { protected feature } \\
\text { of MPAs/MPA } \\
\text { proposals }\end{array}$ \\
\hline 28 & $\begin{array}{l}\text { Inner Hebrides Carbonate } \\
\text { Production Area }\end{array}$ & $\begin{array}{l}25-75 \% \\
\text { (Sea of the Hebrides MPA } \\
\text { proposal) }\end{array}$ & $\begin{array}{l}<25 \% \\
\text { (Rinns of Islay SPA, North Colonsay and Western Cliffs SPA) }\end{array}$ & Yes \\
\hline 29 & $\begin{array}{l}\text { Orkney Carbonate } \\
\text { Production Area }\end{array}$ & $\begin{array}{l}<25 \% \\
\text { (Papa Westray, Wyre and Rousay } \\
\text { Sounds) }\end{array}$ & $\begin{array}{l}<25 \% \\
\text { (East Coast of Sanday SAC, Calf of Eday SPA, Faray and } \\
\text { Holm of Faray SAC, Rousay SPA, West Westray SPA) }\end{array}$ & Yes \\
\hline 30 & $\begin{array}{l}\text { Shetland Carbonate } \\
\text { Production Area }\end{array}$ & $\begin{array}{l}<25 \% \\
\text { (Fetlar to Haroldswick, Mousa to } \\
\text { Boddam) }\end{array}$ & $\begin{array}{l}<25 \% \\
\text { (Mousa SAC, Papa Stour SAC, Sullom Voe SAC, The Vadills } \\
\text { SAC, Yell Sound Coast SAC, Hermaness, Saxa Vord and } \\
\text { Valla Field SPA, Ramna Stacks and Gruney SPA, Otterswick } \\
\text { and Graveland SPA, Fetlar SPA, Ronas Hill - North Roe and } \\
\text { Tingon SPA, Papa Stour SPA, Noss SPA, Fetlar SPA, } \\
\text { Hermaness, Saxa Vord and Valla Field SPA, Mousa SPA, } \\
\text { Sumburgh Head SPA) }\end{array}$ & Yes \\
\hline \multicolumn{5}{|c|}{ Coastal Geomorphology of Scotland } \\
\hline 31 & $\begin{array}{l}\text { St Kilda Archipelago } \\
\text { Submerged Landforms }\end{array}$ & $0 \%$ & $\begin{array}{l}100 \% \\
(\text { St Kilda SAC \& SPA) }\end{array}$ & - \\
\hline 32 & $\begin{array}{l}\text { Sula Sgeir Submerged } \\
\text { Platforms }\end{array}$ & $0 \%$ & $\begin{array}{l}<25 \% \\
\text { (North Rona and Sula Sgeir SPA) }\end{array}$ & - \\
\hline \multicolumn{5}{|c|}{ Biogenic Structures of the Scottish Seabed } \\
\hline 33 & $\begin{array}{l}\text { Rockall Bank Biogenic } \\
\text { Sediment Mounds }\end{array}$ & $0 \%$ & $\begin{array}{l}>75 \% \\
\text { (East Rockall Bank cSAC) }\end{array}$ & - \\
\hline 34 & $\begin{array}{l}\text { Hatton Bank Carbonate } \\
\text { Mounds }\end{array}$ & $0 \%$ & $\begin{array}{l}100 \% \\
\text { (Hatton Bank cSAC and Fisheries Area) }\end{array}$ & - \\
\hline
\end{tabular}




\begin{tabular}{|l|l|l|l|l|}
\hline No. & Geodiversity Key Areas & $\begin{array}{l}\text { Proportion of geodiversity key } \\
\text { areas within Nature } \\
\text { Conservation MPAs/MPA } \\
\text { proposals } \\
(100 \%,>75 \%, 75-25 \%,<25 \%, \\
0 \%)\end{array}$ & $\begin{array}{l}\text { Proportion of geodiversity key areas within other protected } \\
\text { areas covered by existing measures (SACs, SPAs, Fisheries } \\
\text { Areas) } \\
(100 \%,>75 \%, 75-25 \%,<25 \%, 0 \%)\end{array}$ & $\begin{array}{l}\text { Geodiversity } \\
\text { interest } \\
\text { recognised as a } \\
\text { protected feature } \\
\text { of MPAs/MPA } \\
\text { proposals }\end{array}$ \\
\hline 35 & Mingulay Reef & $0 \%$ & $\begin{array}{l}100 \% \\
(\text { East Mingulay cSAC) }\end{array}$ & - \\
\hline
\end{tabular}

1 Negligible overlap.

2 Although the Sea of Hebrides Nature Conservation MPA proposal spatially overlaps The Small Isles, the Quaternary is not included as an interest feature. It is considered unlikely that any management measures developed for the biodiversity interests and for the Marine Geomorphology of the Scottish Shelf Seabed feature, which is included, would afford adequate protection to the extensive Quaternary interests.

3 Much of the North Sea Fan extends beyond UK waters. Of the area within UK waters, $>75 \%$ is contained within the North-east Faroe-Shetland Channel Nature Conservation MPA.

4 Not recognised as a protected feature, but biodiversity related management measures for benthic habitats are considered to afford adequate protection to the underlying geodiversity interests. 


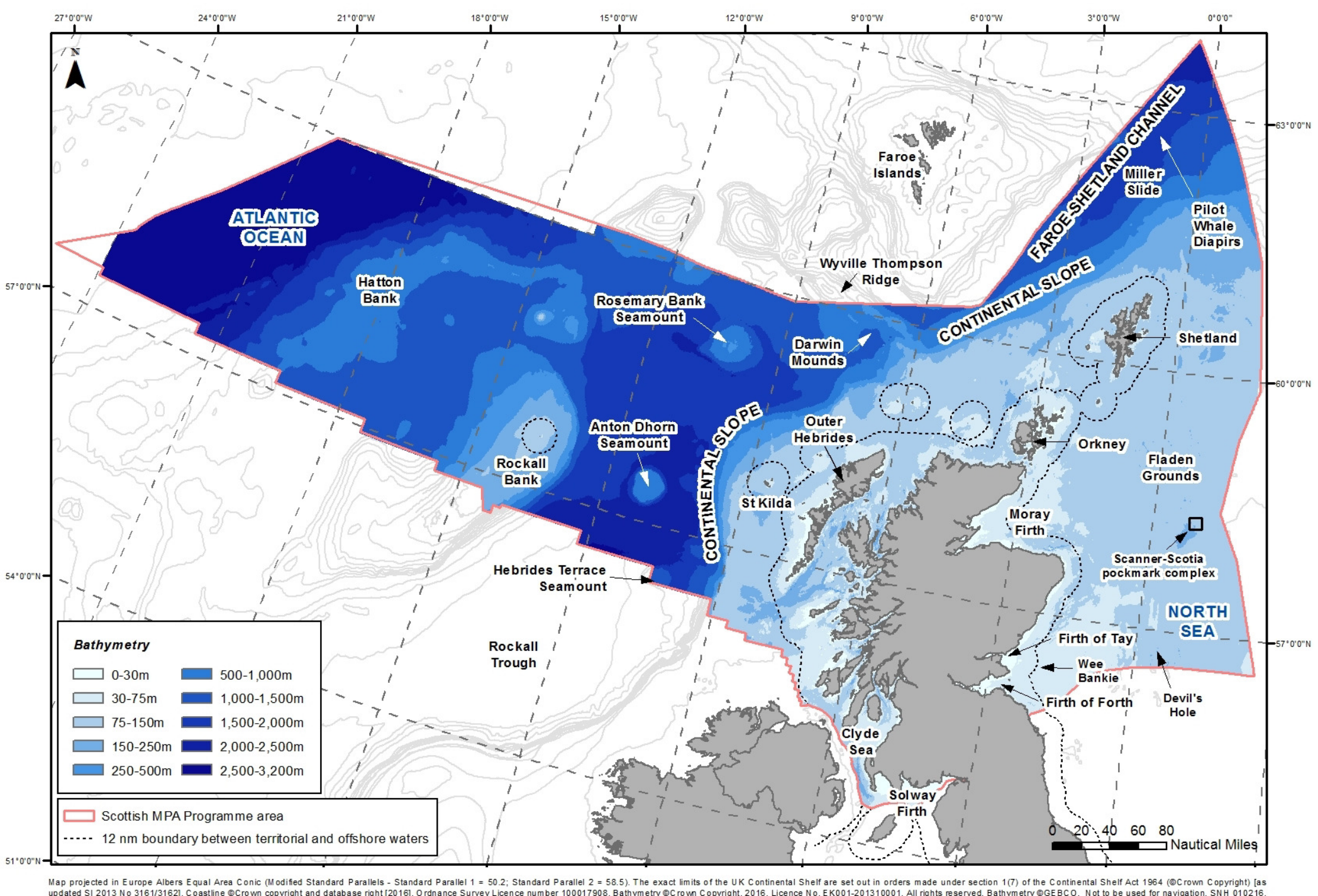

Fig. 1. Extent of Scotland's seas, showing bathymetry and locations of major physiographic features. 


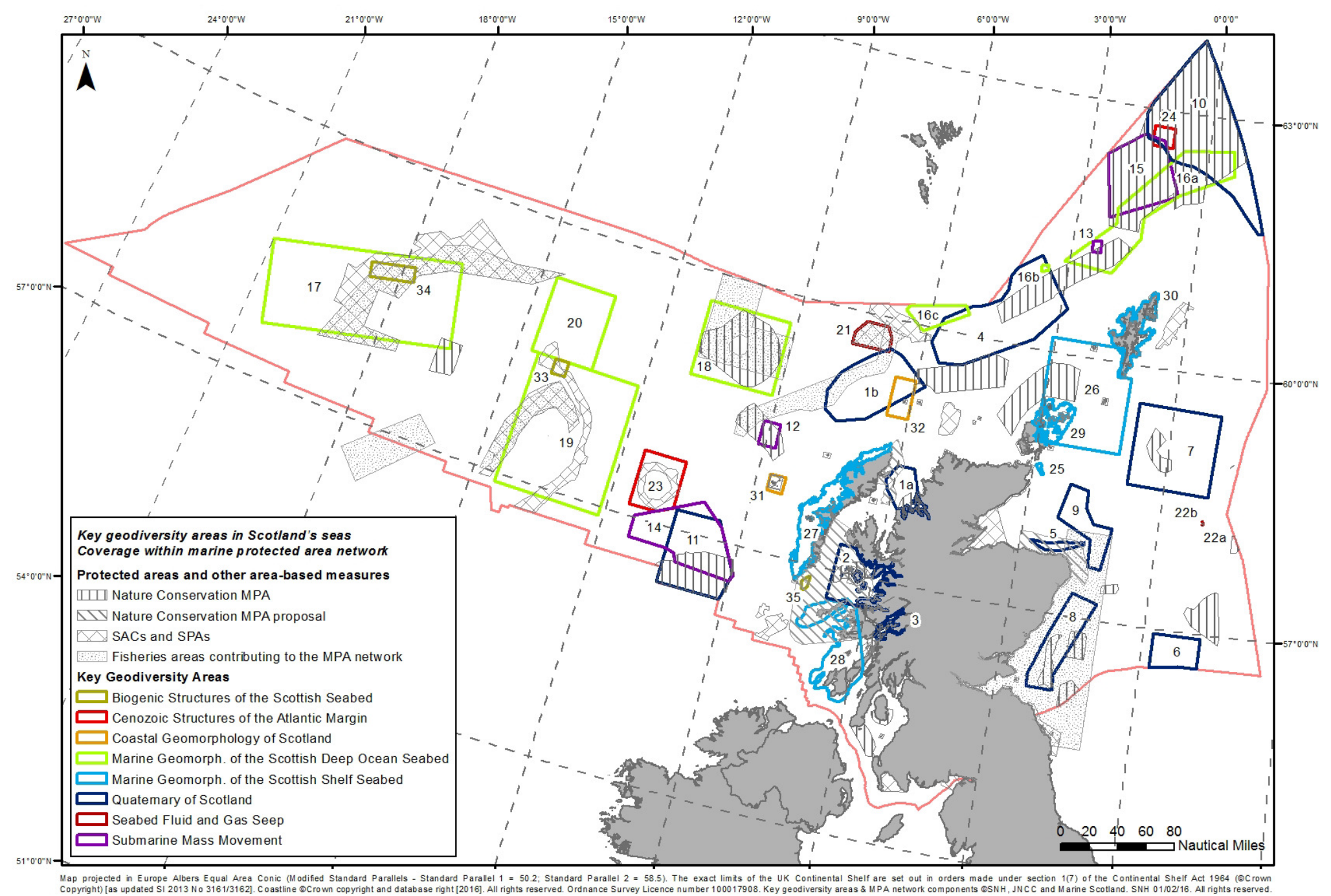

Fig. 2. Geodiversity key areas on the Scottish seabed (numbers refer to key areas listed in Table 4). 